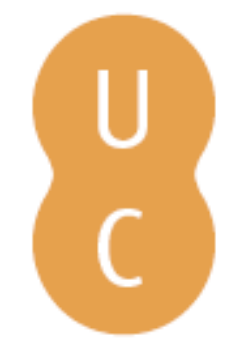

\title{
nommalina
}

\section{Breves reflexões sobre a proteção do unido de facto quanto à casa de morada de família propriedade do companheiro falecido}
Autor(es):
Pedro, Rute Teixeira
Publicado por: Imprensa da Universidade de Coimbra
URL
persistente:
URI:http://hdl.handle.net/10316.2/38888
DOI:
DOI:http://dx.doi.org/10.14195/978-989-26-1113-6_10
Accessed : $\quad$ 26-Apr-2023 06:08:36

A navegação consulta e descarregamento dos títulos inseridos nas Bibliotecas Digitais UC Digitalis, UC Pombalina e UC Impactum, pressupõem a aceitação plena e sem reservas dos Termos e Condições de Uso destas Bibliotecas Digitais, disponíveis em https://digitalis.uc.pt/pt-pt/termos.

Conforme exposto nos referidos Termos e Condições de Uso, o descarregamento de títulos de acesso restrito requer uma licença válida de autorização devendo o utilizador aceder ao(s) documento(s) a partir de um endereço de IP da instituição detentora da supramencionada licença.

Ao utilizador é apenas permitido o descarregamento para uso pessoal, pelo que o emprego do(s) título(s) descarregado(s) para outro fim, designadamente comercial, carece de autorização do respetivo autor ou editor da obra.

Na medida em que todas as obras da UC Digitalis se encontram protegidas pelo Código do Direito de Autor e Direitos Conexos e demais legislação aplicável, toda a cópia, parcial ou total, deste documento, nos casos em que é legalmente admitida, deverá conter ou fazer-se acompanhar por este aviso.

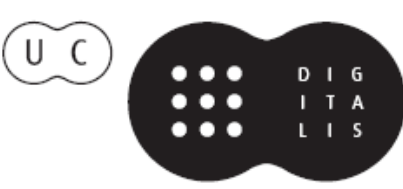




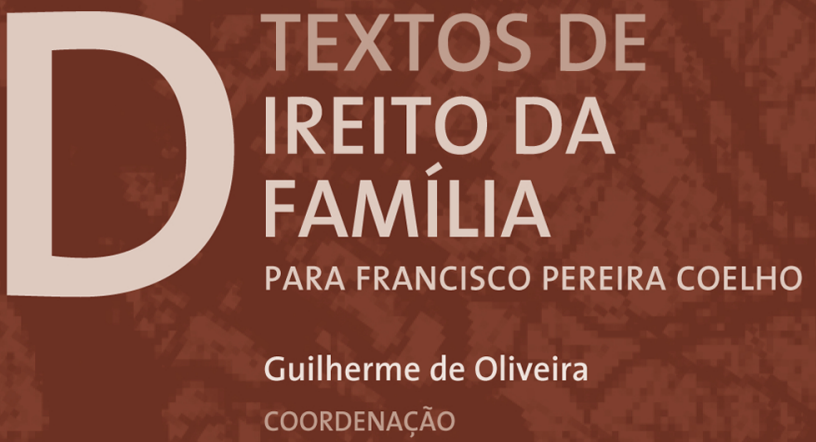




\section{BREVES REFLEXÕES SOBREA PROTEÇÃO DO UNIDO DE FACTO QUANTO À CASA DE MORADA DE FAMÍLIA PROPRIEDADE DOCOMPANHEIRO FALECIDO}

Rute Teixeira Pedro Assistente da Faculdade de Direito da Universidade do Porto

\section{Sumário}

I. O movimento de progressiva ampliação dos efeitos legalmente previstos para a união de facto; II. A proteção do unido de facto sobrevivo relativa à casa de morada de família propriedade do companheiro falecido: 2.1. A evolução até ao regime introduzido pela Lei $n .^{\circ}$ 23/2010, de 30 de agosto; 2.2. O regime vigente consagrado pela Lei $n{ }^{\circ}$ 23/2010, de 30 de agosto 2.3. A imposição da proteção e a insusceptibilidade de afastamento por vontade do de cuius - o estranho caso de um legatário legal forçoso não legitimário? III. Observações conclusivas.

\section{O movimento de progressiva ampliação dos efeitos legal- mente previstos para a união de facto}

I. O reconhecimento crescente de efeitos jurídicos à relação daqueles que vivem como se casados fossem sem o serem - rectius, à relação daqueles que vivem em união de facto - é comummente apresentada como uma das tendências caracterizadoras da evolução 
do direito da família a partir do último terço da centúria passada. Tratou-se de mais uma manifestação do pendor individualista e pluralista que passou a impregnar as soluções acolhidas neste segmento do ordenamento jurídico em consequência das reformas ocorridas nas décadas de sessenta e setenta do século XX. À luz daquela orientação, o direito passou a aceitar, reconhecendo, formas diversas de organização familiar ${ }^{1}$. Entre nós, também se divisa uma tendência evolutiva idêntica iniciada logo - ainda que muito rudimentarmente ${ }^{2}$ - com o Decreto-lei 496/1977, de 25 de novembro $^{3}$, a que se foram juntando, depois, outras inovações pontuais, fruto da intervenção legislativa ou da atuação jurisprudencial' ${ }^{4}$.

${ }^{1}$ GuILHERME OLIVEIRA refere-se a este fenómeno que conduz a um movimento da "unicidade tendencial das formas válidas de matrimónio para a diversidade progressiva, consoante as confissões religiosas e o grau de laicidade dos Estados". In Notas sobre a Lei n. ${ }^{\circ}$ 23/2010, de 30 de agosto (Alteração à Lei das Uniões de facto), in Lex Familiae - Revista Portuguesa de Direito da Família, Ano 7, n. ${ }^{\circ}$ 14, julho/dezembro de 2010, p. 140.

${ }^{2}$ Lia-se no ponto 46 do Preâmbulo do Decreto-lei 496/1977, de 25 de novembro: "Não se foi além de um esboço de proteção, julgado ética e socialmente justificado, ao companheiro que resta de uma união de facto que tenha revelado um mínimo de durabilidade, estabilidade e aparência conjugal. Foi-se intencionalmente pouco arrojado. Havia que não estimular as uniões de facto". Diário da República, I. ${ }^{a}$ Série, de 25 de novembro de 1977, p. 2818 (8).

${ }^{3}$ Este diploma verte pela primeira vez, em letra de forma legal a expressão união de facto, no art. $2020 .^{\circ}$.

${ }^{4}$ Quanto aos efeitos civis, destacam-se as alterações no que respeita ao regime jurídico aplicável ao destino da casa de morada comum após a extinção da relação de união de facto. Por um lado, o legislador com a Lei 46/85, de 20 de setembro, que alterou a redação do então vigente art. $1111 .^{\circ}$ do Código Civil, passa a admitir, no seu n. ${ }^{\circ} 2$, em certas circunstâncias, a não caducidade do direito de arrendamento em caso de morte do arrendatário, consagrando a possibilidade (que se mantém, desde então, na lei, apesar das mudanças de configuração e de inserção sistemática produzidas ao longo do tempo) de transmissão da correspondente posição jurídica ao unido de facto sobrevivo do arrendatário falecido. Por outro lado, no que concerne à situação de rutura da união de facto, divisava-se uma orientação judicial no sentido de estender à união de facto, em determinadas circunstâncias, a aplicação do regime previsto para a dissolução do casamento no art. $1110 .^{\circ}$ e no art. $1793 .^{\circ}$, consoante a casa de morada comum fosse tomada de arrendamento ou fosse propriedade de um dos companheiros. Depois desta intervenção pretoriana, tais soluções viriam a merecer acolhimento legal nas sucessivas leis que disciplinaram a união de facto. Vide PEREIRA COElHo e GUILHERME DE OliVEIRA, Curso 
Considerando estes movimentos reformadores, o Professor Pereira Coelho, pronunciava-se, em meados da década de 80 do século passado, sobre a alteração produzida na imagem da família, admitindo que, atentos os efeitos então reconhecidos à união de facto, esta poderia ser "qualificada como relação de família para determinados efeitos", citando a este propósito, a título ilustrativo, no domínio civil, a eficácia que já the era associada no âmbito do contrato de locação ${ }^{5}$. Ademais o mesmo Autor antevia que, no futuro, aos efeitos já reconhecidos à união de facto se juntassem outros, em homenagem à promoção da concretização de finalidades protecionistas dos sujeitos mais frágeis (em regra, a mulher), à luz de juízos de equidade 6 .

II. Como sabemos, a previsão do ilustre jurista concretizou-se, ampliando-se, desde então, em extensão e intensidade ${ }^{7}$, a eficácia

de Direito da Família, Vol. I. Introdução. Direito Matrimonial, $4 .^{a}$ edição, Coimbra, Coimbra Editora, 2008, pp. 60 e ss.

5 In Casamento e família no Direito Português, in Temas de Direito da Família. Ciclo de Conferências no Conselho Distrital do Porto da Ordem dos Advogados, Coimbra, Livraria Almedina, 1986, pp. 8 e 9. Segundo o parecer do Ilustre Autor, a relação de união de facto não consubstanciava, no entanto, uma relação familiar para a generalidade dos efeitos -, razão pela qual o art. $1576 .^{\circ}$ se manteve (mantém) incólume desde a versão original do Código Civil. Aliás, o Autor, entendendo que o n. ${ }^{\circ} 1$ do art. $36 .{ }^{\circ}$ da Constituição da República Portuguesa (C.R.P.) não importava o reconhecimento da união de facto como relação de família, considerava que a questão não devia "dogmatizar-se excessivamente". Op. cit., p. 9. PEREIRA COELHO ancora, aliás, a proteção constitucional da união de facto no art. $26 .^{\circ}$ da Constituição. Vide do mesmo Autor e de Guilherme De Oliveira, Curso de Direito da Família cit. pp. 55 e ss. Defendendo, hoje, uma leitura atualista da noção jurídica da família constitucionalmente acolhida entre nós sem que isso implique a equiparação do tratamento jurídico previsto para a união de facto e para o casamento, vide CRISTINA ARAÚJO DIAS, Da inclusão Constitucional da união de facto: nova relação familiar, Estudos em homenagem ao Prof. Doutor Jorge Miranda, Vol. VI, FDUL, 2012, pp.451 e ss, em especial, p. 467.

${ }^{6}$ Casamento e família no Direito Português cit., pp. 17 e ss, em especial, pp. 19 e 20.

7 Quando nos referimos à extensão, consideramos, por um lado, a previsão de mais efeitos que podem ser associados à vivência em união de facto (vide a consagração, na Lei 7/2001, de 11 de maio, da possibilidade de adoção conjunta pelos companheiros quando exista diversidade de sexo entre eles) e, por outro lado, o alargamento do âmbito subjetivo da proteção que lhe é reconhecida (resultante, por exemplo, da equiparação parcial, operada pela citada lei, quanto aos efeitos produzidos, entre as uniões de facto homossexuais e as uniões de facto heterosse- 
jurídica legalmente associada à relação de união de facto, atendendo à proximidade existencial subjacente à comunhão de vida que a carateriza e às dependências que daí emergem. Como principais marcos miliares desse iter - que já foi apelidado de institucionalização da união de facto $^{8}$-, aparecem, primeiro, a Lei 135/1999, de 28 de agosto, depois, a Lei 7/2001, de 11 de março (que substituiu a primeira) e, por fim, a Lei 23/2010, de 30 de agosto (que altera a segunda). Apesar da paulatina dilatação da eficácia jurídica operada por tais leis, o modelo de intervenção do direito nesta área da vida mantém-se incólume. Nessa medida, continua a acolher-se, neste domínio, uma proteção fragmentária e especialmente dirigida a cenários de crise em que as debilidades dos seus membros se concretizam ou manifestam com mais intensidade. É, então, nesses momentos que se torna necessária a ingerência jurídica através de "soluções de tipo "assistencial»"9. Por consequência, apesar de se divisar um movimento de entibiamento dos efeitos associados ao casamento, as relações matrimoniais e as relações de união de facto mantêm-se distantes ${ }^{10}$, como, aliás, demandam as diretrizes constitucionais ${ }^{11}$.

xuais). Quando pensamos na acentuação da intensidade dos efeitos, referimo-nos ao robustecimento da proteção que já se encontrava prevista. O regime sobre que nos vamos debruçar é um bom exemplo desta última espécie".

8 Pereira Coelho e Guilherme Oliveira, Curso de Direito da Família cit., p. 60 .

9 Guilherme De Oliveira, In Notas sobre a Lei $n .{ }^{\circ}$ 23/2010, de 30 de agosto (Alteração à Lei das Uniões de facto) cit., p. 153.

10 Pereira COElHo, com o objetivo de comparar a eficácia jurídica respetiva, cotejava em meados da década de 80 do século passado, os efeitos civis da união de facto com os do casamento, concluindo que a diferença era acentuada. In Casamento e família no Direito Português cit., pp. 15 a 17. A distância, hoje, permanece "abissal", na expressão de GUILHERME DE OlIVEIRA, op. ult. cit., p. 153.

11 Pereira Coelho e Guilherme Oliveira, Curso de Direito da Família cit., p. 58. Sobre a garantia institucional do casamento, vide RITA LOBO XAVIER, A garantia institucional do casamento, o legislador democrático e o Tribunal Constitucional: cuis custodiet ipsos custodes?, in Estudos em homenagem ao Prof. Doutor Jorge Miranda, Vol. III, FDUL, 2012, pp. 601 e ss. 
A união de facto continua, assim, ainda, a ser, fundamentalmente um espaço de não direito ${ }^{12}$.

III. A diferente natureza da intervenção jurídica nas duas relações referidas pode ser ilustrada pela diversidade de efeitos civis $^{13}$ associados à morte de um unido de facto ou de um cônjuge ${ }^{14}$, em benefício, respetivamente, do companheiro e do cônjuge sobrevivos.

Na verdade, desde a Reforma de 1977, o cônjuge figura, no art. 2157. do Código Civil, como herdeiro legitimário numa categoria em que também se incluem os descendentes e os ascendentes. Diversamente, o unido de facto sobrevivo não se inscreve nesse círculo de herdeiros forçosos. Para além da proteção de natureza alimentar consagrada no art. $2020 .^{\circ}$, vinda da mesma reforma da década de 70 do século passado, o legislador reconhece-lhe, desde 1999, alguns direitos sobre um determinado bem - aquele em que se situe a casa de morada de família -, quando o mesmo, por ser propriedade do unido de facto falecido, integre o respetivo património hereditário. Falamos da solução, inicialmente introduzida nos números 1 e 2 do artigo $4^{\circ}$ da Lei 135/99, de 28 de agosto, que depois transitou, com pequenas alterações, para os números 1 e 2 do art. $4 .^{\circ}$ da Lei $7 / 2001$, de 11 de maio e que, hoje, consta do art. $5 .^{\circ}$ da mesma Lei, na versão reformulada pela Lei n. ${ }^{\circ}$ 23/2010, de 30 de agosto.

É, então, sobre essa disciplina que nos pretendemos debruçar neste trabalho. Trata-se, hoje, como veremos, de um regime jurídico

12 A união de facto "deve continuar a ser não jurídica", na síntese de GUILHERME Oliveira, In Notas sobre a Lei $n .^{\circ}$ 23/2010, de 30 de agosto (Alteração à Lei das Uniões de facto) cit., p. 140.

13 Considerando o objeto destas reflexões, concentramo-nos nos efeitos civis, deixando de lado outros efeitos, nomeadamente no que concerne aos direitos a prestações sociais previstos na al. e) do $n .^{\circ} 1$ art. $3 .^{\circ}$ da Lei $7 / 2001$, de 11 de maio, na redação vigente.

${ }^{14}$ Apesar da previsão de proteção alimentar, quer para o cônjuge sobrevivo, quer para o unido de facto supérstite, nos termos dos artigos $2018 .^{\circ}$ e $2020 .^{\circ}$, respetivamente, do Código Civil. 
intrincado traduzido no reconhecimento ao unido de facto de um feixe de direitos relativos à casa de morada de família, em caso de morte do companheiro proprietário da mesma. A conjugação e (re) configuração dos mesmos conduziram ao reforço da tutela dessa posição jurídica, numa extensão, cuja exata dimensão (nem sempre antecipável) dependerá dos contornos do caso concreto, dada a ductilidade que, como veremos, foi comunicada à disciplina na última reforma que sobre ela incidiu.

Antes ainda de nos determos no regime atual, importa perceber o seu surgimento na linha da história recente da proteção da união de facto, o que faremos de imediato.

\section{A proteção do unido de facto sobrevivo relativa à casa de morada de família propriedade do companheiro falecido}

\subsection{A evolução até ao regime introduzido pela Lei $n .^{\circ} 23 / 2010$,} de 30 de agosto

I. No que respeita à problemática que nos ocupa, a proteção do unido de facto, em caso de morte de um dos companheiros, quanto à casa de morada de família propriedade do falecido, encontra o seu marco inicial na Lei 135/99, de 28 de agosto.

$\mathrm{Na}$ verdade, contrastando com o espírito fundamentalmente recompilador deste diploma em que se agregavam soluções já contempladas noutros pontos do ordenamento jurídico (vide art. $3 .^{\circ}$ da citada Lei), no regime previsto para a proteção da casa de morada de família, em caso de extinção da relação de união de facto por morte ou rutura (art. $4 .^{\circ}$ e art. 5. ${ }^{\circ}$ da mesma Lei), detetavam-se algumas inovações ${ }^{15}$,

15 Referindo-se ao regime consagrado na Lei 135/99, de 28 de agosto, e sublinhando que a inovação se situou nesse ponto, vide RITA LOBO XAVIER, Novas sobre a união "more uxorio" em Portugal, in Estudos dedicados ao Prof. Doutor 
no plano legislativo ${ }^{16}$. De entre as mesmas, destacava-se a disciplina consagrada para a hipótese de morte do membro da união de facto proprietário da casa de morada $\operatorname{comum}^{17}$. Nesse caso $^{18}$, segundo o n. ${ }^{\circ} 1$ do art. $4 .^{\circ}$ da referida lei, ao membro sobrevivo era, inovadoramente, reconhecido o direito real de habitação sobre a mesma pelo prazo de cinco anos, assim como um direito de preferência na sua venda ou arrendamento. Logo no n. ${ }^{\circ} 2$ do mesmo preceito, se previa o afastamento do reconhecimento de tal direito, quando existisse disposição testamentária em contrário ou quando ao falecido proprietário da casa sobrevivessem descendentes ou ascendentes que com ele vivessem há pelo menos um ano, no caso de os mesmos aí pretenderem continuar a habitar.

II. Apesar de, na Lei $7 / 2001$, de 11 de maio - que revoga a Lei $135 / 99$, de 28 de agosto, congregando num novo diploma as medidas de proteção das uniões de facto - se integrarem algumas novidades ${ }^{19}$, o regime relativo à casa de morada comum, em caso de morte do unido de facto proprietário da mesma, permaneceu em larga medida intocado. Na verdade, para além de outras mudanças

Mário Júlio de Almeida Costa, Universidade Católica Portuguesa, 2002, pp. 1393 e ss, em especial, p. 1399.

16 Dizemos no plano legislativo, dado que a proteção da casa de morada de família prevista no n. ${ }^{\circ} 3$ e no.$^{\circ} 4$ do art. $4 .^{\circ}$ da Lei $135 / 99$, de 28 de agosto, para o caso de rutura da relação (por aplicação do disposto no n. ${ }^{\circ} 2$ do artigo $84 .^{\circ}$ do Regime do Arrendamento Urbano ou no artigo $1793 .^{\circ}$ do Código Civil, consoante a casa de morada de família se situasse num imóvel arrendado ao unido de facto falecido ou propriedade do mesmo, respetivamente) já era reconhecida, em certas circunstâncias, pela jurisprudência, como referimos na nota 4 .

17 No caso de a casa ser arrendada a um dos unidos de facto, e de o arrendatário morrer, a proteção do sobrevivo já era assegurada pelo disposto no art. $85 .{ }^{\circ}$ do RAU que a Lei 135/99, de 28 de Agosto, no seu art. $5 .^{\circ}$, veio reformular.

18 Sobre este regime, vide FRANÇA PITÃo, União de Facto no Direito Português. A propósito da Lei n. ${ }^{\circ}$ 135/99, de 28/08, Coimbra, Almedina, 2000, pp. 156 a 168.

19 Nomeadamente a equiparação parcial das uniões de facto homossexuais e heterossexuais e a previsão do direito de adoção conjunta para os casais de unidos de facto formados por sujeitos de sexo diferente. 
de natureza essencialmente formal ${ }^{20}$, a alteração concretiza-se apenas na eliminação da previsão do direito de preferência em caso de arrendamento e na modificação das causas de denegação do direito real de habitação previstas no n. ${ }^{\circ} 2$ do art. $4 .^{\circ}$ da referida lei. Assim, dava-se, por um lado, o desaparecimento da previsão, como hipótese excludente desse direito, da sobrevivência ao de cuius de ascendentes e, por outro lado, quanto à existência de descendentes do unido de facto ao tempo da ocorrência da morte deste, reformulavam-se as constelações fácticas em que a mesma conduzia a idêntico resultado denegatório ${ }^{21}$.

III. A tutela concentrava-se, então, num direito real de habitação sobre a casa de morada de família durante um período de 5 anos contados a partir da data da morte do respetivo proprietário. Tratavase, no entanto, em qualquer das duas versões, de uma proteção duplamente enfraquecida: por um lado, pela natureza supletiva do regime, ao deixar-se na disponibilidade do unido de facto proprietário do imóvel a sua aplicação, permitindo-lhe que a afastasse por manifestação de vontade contrária em testamento ${ }^{22}$; por outro lado, pela prevalência atribuída aos interesses de certos parentes na linha reta em detrimento dos interesses do unido de facto sobrevivo.

IV. A Lei n. ${ }^{\circ}$ 23/2010, de 30 de agosto, vem alterar, mais profundamente, o quadro normativo de que falamos. O legislador opera, então, uma reestruturação da sistematização escolhida para apre-

${ }^{20} \mathrm{Na}$ epígrafe, adita-se a menção à "residência comum" e, no corpo do artigo, para além de uma inversão da ordem das palavras, que antecipou a referência ao intervalo temporal em que os dois direitos previstos no n. ${ }^{\circ} 1$ se aplicam, substitui-se a expressão "casa de morada do casal" por "casa de morada comum" (n. $\left.{ }^{\circ} 1\right)$, e o verbo "viver" por "conviver" $\left(\mathrm{n} .^{\circ} 2\right)$.

${ }^{21}$ Destacava-se, quanto os descendentes, o caso de se tratar de filhos com menos de 1 ano de idade, situação em que não se demandava que vivessem com o falecido progenitor proprietário do imóvel há mais de um ano.

22 O sentido da expressão "no caso de disposição testamentária em contrário" não era unívoco, levantando algumas questões. Sobre esta problemática, veja-se FRANÇA PITÃO, Uniões de facto e Economia Comum, $2 .^{a}$ ed revista e atualizada, Coimbra, Almedina, 2006, pp. 256 e 257. 
sentar a proteção relativa à casa de morada de família a que se refere globalmente na al. a) do n. ${ }^{\circ} 1$ do art. 3..$^{\circ}$ da L.U.F. ${ }^{23}$. Assim, autonomiza a previsão das soluções relativas à situação de rutura da relação, vertendo-as no corpo do novo art. 4. . Por outro lado, agrega, no artigo 5. ${ }^{\circ}$, a disciplina aplicável à hipótese de dissolução da relação por morte de um dos unidos de facto, quer a casa seja propriedade do de cuius, quer lhe tenha sido arrendada. Para este último caso, reserva-se o n. ${ }^{\circ} 10$ do referido artigo que dita a aplicação do disposto no art. $1106 .^{\circ}$ do Código Civil. Para a situação que nos ocupa, de o de cuius ser titular do direito de propriedade sobre a casa de morada de família ${ }^{24}$, o regime consta, agora, dos números 1 a 9 do mesmo artigo. Cumprirá, então, considerar o que de substancial mudou com esta reformulação.

De forma sintética, e ainda antes de nos determos mais detalhadamente sobre a disciplina reformada, importa referir que o legislador veio aumentar o conjunto de direitos previstos, ampliando, em vários pontos, a eficácia dos mecanismos jurídicos em que se plasma a tutela de que falamos. Em primeiro lugar, ao direito real de habitação sobre a casa de morada de família acrescenta um direito real de uso sobre o recheio da mesma (n..$^{\circ} 1$ do art. $5 .^{\circ}$ ). Em segundo lugar, muda o modo de determinação do período temporal em que esses direitos se poderão exercitar, passando a duração de 5 anos, tabelada anteriormente de forma fixa e universal para todas as situações, a constituir, agora, em princípio ${ }^{25}$, somente a duração

23 Vamos empregar esta abreviatura para nos referirmos, a partir deste ponto, à Lei 7/2001, de 11 de maio, na redação que lhe foi dada pela Lei 23/2010, de 30 de agosto. Acresce que, quando citarmos algum artigo sem referência ao diploma que pertence, deve entender-se que integra a mesma versão de tal lei.

24 O que abrange, como veremos, não só a hipótese de ele ser o proprietário exclusivo da mesma, mas também a hipótese de ele ser dela comproprietário com o outro unido de facto, como expressamente, hoje, se prevê no n. ${ }^{\circ} 2$ art. 5. ${ }^{\circ}$ da L.U.F..

25 Como referiremos, nos números 5 e 6 do art. $5 .^{\circ}$ da L.U.F., prevêem-se causas de não reconhecimento $a b$ initio ou de caducidade dos direitos referidos. 
mínima de subsistência dos mesmos (números 2 e 4 do art. 5. ${ }^{\circ}$ ). Em terceiro lugar, elimina as causas de exclusão desses direitos, anteriormente previstas no n. ${ }^{\circ} 2$ do art. 4 . $^{\circ}$. Por consequência, inviabiliza-se a possibilidade de o unido de facto proprietário do imóvel e do respetivo recheio afastar, por declaração de vontade, o reconhecimento dos referidos direitos e dá-se prioridade à tutela do interesse do unido de facto sobrevivo na continuidade da ligação à esfera física em que vivera até à morte do companheiro, em detrimento da proteção de outros parentes do falecido. Em quarto lugar, destaca-se a atribuição ao unido de facto, findo o intervalo temporal em que beneficiou do direito real de habitação, de um direito à celebração de um contrato de arrendamento do imóvel nas condições gerais do mercado, permitindo-se que o mesmo continue a residir no local até à celebração desse contrato (n. 7 do art. 5. $^{\circ}$ ). Em quinto lugar, mantendo-se o reconhecimento do direito de preferência em caso de venda do imóvel, a previsão contida no $n .^{\circ} 9$ do artigo $5 .^{\circ}$ dá-lhe uma nova configuração que muda, em alguns pontos, os contornos que o mesmo apresenta.

O regime hoje vigente compõe-se, então, da articulação de um conjunto de direitos que promovem a tutela do unido de facto sobrevivo na situação considerada. Na verdade, apesar de se preverem alguns limites ao exercício dos citados direitos, a ponderação global do novo regime, conduzirá, em regra, a um reforço da posição jurídica do unido de facto relativamente à casa de morada de família, quando o companheiro falecido fosse proprietário da mesma. Vejamos, mais de perto, este complexo articulado de direitos, desdobrando a sua análise em 3 partes. Falaremos, em primeiro lugar, nos direitos de habitação da casa de morada comum e de uso do respetivo recheio, em segundo lugar, do direito à celebração do contrato de arrendamento do imóvel e, em terceiro lugar, no direito de preferência em caso de alienação do mesmo. 
2.2. O regime vigente consagrado pela Lei $n .^{\circ} 23 / 2010$, de 30 de agosto

a) Direito de habitação da casa de morada de família e direito de uso do respetivo recheio

I. Na redação vigente da Lei $7 / 2001$, de 11 de maio, no que respeita à proteção da casa de morada de família em caso de morte de um dos unidos de facto, quando este seja (com)proprietário da mesma, avulta o reconhecimento, ao companheiro sobrevivo, dos direitos de habitação sobre o imóvel e de uso sobre o respetivo recheio, nos termos do n. ${ }^{\circ} 1$ do art. 5. ${ }^{\circ 26}$. A previsão, inovadora no âmbito da união de facto, deste último direito constituirá um mecanismo que permite tutelar "mais eficazmente a continuidade do lar que viveu em união de facto", servindo-nos das palavras de Guilherme Oliveira ${ }^{27}$.

A consagração deste binómio de direitos aproxima-se do disposto no art. $2103{ }^{\circ}$-A do Código Civil em benefício do cônjuge sobrevivo, embora não haja coincidência das previsões normativas. Na verdade, para além da diferente articulação com o fenómeno sucessório nos termos em que nos referiremos infra ${ }^{28}$, enquanto os direitos do cônjuge serão tendencialmente vitalícios ${ }^{29}$, os direitos do unido de facto apresentam-se como temporários, estendendo-se, em regra, por um período mínimo de cinco anos, embora possam prolongar-se por um intervalo temporal mais extenso, sem nunca, no entanto, pela sua natureza, ultrapassar a vida do respetivo titular.

\footnotetext{
${ }^{26}$ A situação considerada pelo legislador terá sido a de o unido de facto falecido ser proprietário da casa e do respetivo recheio, havendo a possibilidade de um exercício conjunto dos dois direitos. Mas e se tal não acontecer? Não parece haver óbice a que os direitos possam ser exercidos separadamente.

27 In Notas sobre a Lei $n .^{\circ}$ 23/2010, de 30 de agosto (Alteração à Lei das Uniões de facto) cit., p. 145.

${ }^{28} \mathrm{Na}$ medida em que o art. 2103. ${ }^{\circ}$-A do Código Civil prevê uma atribuição preferencial do cônjuge a ser exercida pelo mesmo, como herdeiro legitimário, na partilha.

29 Veja-se, no entanto, o disposto no n. ${ }^{\circ} 2$ do art. 2013. ${ }^{\circ}$-A do Código Civil.
} 
Em comum existe, assim, a previsão legal dos direitos referidos, em benefício do cônjuge ou daquele que viveu em condições análogas às dos cônjuges com o proprietário da casa de morada de família e/ou do seu recheio, o que redundou na atribuição de relevância aos direitos previstos nos art. $1484 .^{\circ}$ e ss do Código Civil 30 que, na prática, têm sido votados ao esquecimento e à consequente não aplicação no plano dos factos ${ }^{31}$.

II. Trata-se de dois direitos reais menores ${ }^{32}$ que proporcionam ao seu titular faculdades de uso (jus utendi) das coisas a que respei$\operatorname{tam}^{33}$. O direito de uso abrangerá, também, poderes de fruição (ius fruendi), permitindo, portanto, o aproveitamento dos frutos gerados pelas coisas objeto do mesmo ${ }^{34}$. Em qualquer caso, estarão excluídos poderes de disposição relativamente às coisas sobre que incidem.

\footnotetext{
30 A partir deste ponto, usaremos a abreviatura C.C. para nos referirmos ao Código Civil.
}

31 A previsão dos direitos de uso e habitação no Código Civil de 1966 não foi acompanhada pela sua relevância em termos práticos, apresentando-se pouco frequente a constituição voluntária de tais direitos, por contrato ou testamento, à luz do art. $1440{ }^{\circ}$ por remissão do art. $1485 .^{\circ}$ do Código Civil. Neste sentido, LUís CARVALHO FERNANDES, Lições de Direitos Reais, 6. ${ }^{a}$ edição atualizada e revista, Lisboa, Quid iuris Sociedade Editora, 2009, p. 426. Aquele cenário sofreria alteração, em virtude de disposições legais posteriores que preveem a constituição de direitos daquela espécie, em homenagem à proteção valores de ordem familiar. Primeiramente, dá-se a introdução, no Código Civil, pelo Decreto-lei 496/77, de 25 de novembro, dos artigos $2103 .^{\circ}$-A a $2103 .^{\circ}$-C que concedem ao cônjuge viúvo as já assinaladas atribuições preferenciais na partilha do património hereditário do seu consorte. Duas décadas mais tarde, na Lei n. ${ }^{\circ}$ 135/99, de 28 de agosto, prevê-se, em favor do unido de facto sobrevivo, a atribuição de um direito de habitação sobre a casa de morada comum, transitando tal previsão normativa para a Lei $7 / 2001$, de 11 de maio. Em 2010, nos termos referidos em texto, acrescenta-se a consagração legal de um direito de uso sobre o respetivo recheio.

32 "Qualquer deles pressupõe sempre um direito mais extenso, que tanto pode ser a propriedade, a propriedade horizontal, o direito de superfície, ou o usufruto". LUÍs CARVAlHO FERnANDES, Lições de Direitos Reais cit., p. 426.

33 À luz do n. ${ }^{\circ} 1$ do art. 5. ${ }^{\circ}$ da Lei 7/2001, de 11 de maio, e em conformidade com o disposto no n. ${ }^{\circ} 2$ do art. $1484 .^{\circ}$ do C.C., o direito de habitação respeita à casa de morada de família e o direito de uso respeita aos bens móveis que compõem o recheio da casa.

34 Seguimos, aqui, LUÍs CARVALHO FERNANDES que assinala diferenças entre os dois direitos, na medida em que o direito de uso abrangerá, para além de poderes 
Acresce que o poder de gozo proporcionado ao morador usuário e os poderes de gozo e fruição facultados ao usuário não são plenos, antes se circunscrevendo finalisticamente ${ }^{35}$. Na verdade, o teor do licere de tais direitos encontra-se funcionalizado e limitado segundo o fim a que os mesmos se encontram adstritos que é o da satisfação das necessidades pessoais do respetivo titular e da sua família, nos termos do n. ${ }^{\circ} 1$ do art. $1484 .^{\circ}$ do C.C. ${ }^{36}$.

A estes direitos subjaz, portanto, um objetivo de natureza alimentar e, também por isso, apresentam um caráter pessoalíssimo ${ }^{37}$. Por consequência está arredada qualquer possibilidade de alienação ou oneração dos direitos de uso ou de habitação. Tais direitos estão, assim, cobertos por um manto de intransmissibilidade absoluta (art. $1488 .^{\circ}$ do C.C. $)^{38}$.

O unido de facto poderá, então, permanecer no imóvel que constituiu a casa de morada de família, aí continuando a habitar ${ }^{39}$, e

(limitados) de uso, poderes (limitados) de fruição (ius fruendi), enquanto o direito de habitação abrangerá somente poderes (limitados) de uso. Daí que o Autor conclua que a designação "direito de uso" se adequaria mais ao direito de habitação. Lições de Direitos Reais cit., p. 426.

35 Assim, Luís CARVAlHo FERNANDES destaca "a circunstância de os poderes de uso ou de fruição serem reconhecidos ao titular segundo um critério finalista e não em termos absolutos, de gozo pleno. A sua medida é a das necessidades do seu titular e da respetiva família. São, pois, limitados pelo fim”. Idem. Os itálicos encontram-se no original.

${ }^{36}$ Essa é, aliás, a nota característica mais significativa da distinção entre o direito de uso e de habitação e o direito de usufruto, segundo LUís MENEZES LEITÃo. In Direitos Reais, $3 .^{a}$ edição, Coimbra, Almedina, 2012, p. 346. Sobre esta distinção, vide, também, Luís CARVALHO FERNANDES, Lições de Direitos Reais cit., p. 430. Esta limitação repercute-se na indisponibilidade absoluta dos direitos de uso e de habitação. GALVÃo TElLES, in Direito das Sucessões. Noções Fundamentais, $6{ }^{a}{ }^{\text {edição, }}$ reimpressão, Coimbra, Coimbra Editora, 1996, pp. 65 e 72.

37 Assim, Luís Carvalho Fernandes, Lições de Direitos Reais cit., p. 430.

38 Consubstanciando uma hipótese de intransmissibilidade absoluta, haverá uma insusceptibilidade de transmissão inter vivos e uma inereditibilidade mortis causa desses direitos. GAlvão TElles, Curso do Direito das Sucessões cit., pp. 65 e 72.

39 Considere-se que, quanto ao direito de habitação, atendendo ao objeto sobre que recai - a casa de morada de família - o gozo facultado ao respetivo titular está limitado à finalidade habitacional. O titular do direito de habitação só pode, portanto, servir-se do imóvel para nele viver. Diversamente, o direito de uso propor- 
poderá usar os móveis que compõem o respetivo recheio, aproveitando os eventuais frutos que, por estes, sejam gerados. Estas faculdades poderão ser exercidas na medida das necessidades desse sujeito e da sua família. Para este efeito, o legislador delimita, no art. 1487..$^{\circ}$ do C.C., o perímetro que deve ser reconhecido ao agregado familiar, desviando-se do âmbito que lhe seria assinalado de acordo com o disposto no art. 1576 do C.C. ${ }^{40}$. Ademais manda aferir aquelas

ciona a faculdade de uso apenas circunscrito pelo limite geral representado pelas necessidades pessoais e familiares do respetivo titular. Assim, note-se que, quando um direito de uso recai sobre um prédio urbano indiferenciado o respetivo titular pode, em princípio, usá-lo para fins diversos que não apenas o habitacional. Neste caso (que não se confunde, portanto, com a previsão legal que estamos a analisar em texto), pode, assim, o usuário de um tal imóvel, aí, instalar, por exemplo, um estabelecimento comercial. Neste sentido, veja-se ANTUNES VARELA e PIRES DE LIMA, Código Civil Anotado, Vol. III, 2. ${ }^{a}$ edição, Coimbra, Coimbra Editora, 1987, Anotação ao art. $1484 .^{\circ}$, p. 547.

40 Segundo o art. $1487 .^{\circ}$ do C.C., a família do usuário ou do morador usuário compreende o cônjuge, não separado judicialmente de pessoas e bens, os filhos solteiros, outros parentes a quem sejam devidos alimentos e as pessoas que, convivendo com o titular dos direitos, se encontrem ao seu serviço ou ao serviço das pessoas enunciadas. O círculo de pessoas assim delimitado fica, em certos pontos, aquém do que resultaria da aplicação do art. $1576 .^{\circ}$ (não se abrangem todos os parentes, nem sequer se abrangem indiferenciadamente todos os filhos, não se incluindo também, nem os afins nem os adotados restritamente) e, noutros, vai além, ultrapassando-o (veja-se a parte final do art. $1487 .^{\circ}$ ). Na solução assim adotada, o legislador terá tido em atenção a finalidade alimentar ou assistencial que subjaz à constituição dos direitos de uso e habitação. Sobre a opção legislativa plasmada no art. $1487 .^{\circ}$, veja-se ANTUNes VARela e PIRES DE LIMA, Código Civil Anotado cit., Anotação ao art. $1487 .^{\circ}$, p. 549 e 550. A aplicação deste artigo aos direitos de uso e habitação reconhecidos ao unido de facto sobrevivo pode levantar algumas dificuldades. FRANÇA PITÃO, considerando que não deve ser abrangido o cônjuge do companheiro supérstite - que, atendendo ao disposto no at. ${ }^{\circ} 2 .^{\circ} \mathrm{c}$ ) da L.U.F., terá que provir de um casamento celebrado depois da data de morte do companheiro proprietário da casa e/ou do respetivo recheio -, defende uma interpretação restritiva da aplicação do art. $1487 .^{\circ}$, no sentido em que, para esse efeito, seriam consideradas somente as pessoas que se encontram numa das situações elencadas no referido artigo, ao tempo da morte do unido de facto falecido. In Uniões de facto e Economia Comum, 3. ${ }^{\mathrm{a}}$ ed. revista e atualizada, Coimbra, Almedina, 2011, p. 211. Segundo o Autor, ressalvar-se-iam dessa delimitação temporalmente definida, aquelas pessoas que se subsumem à parte final do artigo, por serem sujeitos que, convivem com o unido de facto sobrevivo, apenas por se encontrarem ao seu serviço ou ao serviço das pessoas enunciadas no art. $1487 .{ }^{\circ}$. Nessa medida, tal situação poderá cessar em virtude da extinção do título (por exemplo, o contrato de trabalho) que justificava essa convivência, o que poderá tornar necessária a sua substituição por outras pessoas que passem a desempenhar idênticas funções. Julgamos que o 
necessidades à luz de um critério subjetivo que atende à condição social do titular dos direitos (art. 1486. ${ }^{\circ}$ do C.C.) ${ }^{41}$.

III. Depois de, com brevidade, descrevermos o conteúdo e a natureza dos direitos previstos no $n .^{\circ} 1$ do art. 5..$^{\circ}$ da L.U.F., curaremos, agora, de enunciar os pressupostos de que depende o seu reconhecimento ao unido de facto sobrevivo.

Em primeiro lugar, será necessária a existência pretérita (porquanto entretanto dissolvida nos termos a que, de imediato, nos referiremos) de uma união de facto eficaz. Assim, exige-se que o respetivo beneficiário vivesse com o titular dos bens sobre que incidirão os direitos reais referidos em condições análogas às dos cônjuges e que essa comunhão de leito, mesa e habitação (tori, mensae et habitationis) tenha durado por um período mínimo de dois $\operatorname{anos}$ (n. ${ }^{\circ} 2$ do art. 1. ${ }^{\circ}$ da L.U.F.).

Em segundo lugar, demanda-se que a relação de união de facto se dissolva por morte de um dos membros que a compõem, nos termos da al. a) do n. ${ }^{\circ} 1$ do art. $8 .^{\circ}$ da L.U.F.. A morte de um dos

entendimento do ilustre Autor pode conduzir a resultados não pretendidos pelo mesmo. Consideremos, então, a hipótese de o unido de facto sobrevivo dar à luz, durante o período de vigência dos direitos de uso e habitação, um filho (que pode ser filho e, portanto, também herdeiro, do unido de facto falecido, o que, na ausência de perfilhação - que poderia acontecer validamente se tivesse ocorrido posteriormente ao momento da conceção, segundo o art. $1855 .^{\circ}$ - importará para o seu estabelecimento jurídico, a propositura de uma ação judicial para reconhecimento de paternidade, nos termos dos artigos $1869 .^{\circ}$ e ss e $1819 .^{\circ}$ ex vi da remissão contida no art. $\left.1873 .^{\circ}\right)$. Deverá o mesmo ser excluído para delimitação das necessidades familiares do titular dos direitos? Julgamos que não. Mas a essa conclusão seríamos conduzidos à luz da interpretação referida, dado que a ressalva formulada não abrangeria esta hipótese. Ora, admitindo que, na hipótese de o unido de facto sobrevivo se casar, no período de vigência dos assinalados direitos, tal facto deva justificar a exclusão do respetivo cônjuge do âmbito do art. $1487 .^{\circ}$, acarretando até a extinção dos direitos (atente-se no dever de coabitação a que os cônjuges se encontram vinculados e cujo cumprimento a isso poderá conduzir), e entendendo, portanto, que o legislador não previu essa hipótese carecida de solução jurídica, julgamos que se pode equacionar o preenchimento de tal lacuna, recorrendo ao lugar paralelo que se divisa no art. 2019. ${ }^{\circ}$, atenta à finalidade alimentar que subjaz aos direitos de uso e habitação. Não podemos, no entanto, deixar de referir que o fim prosseguido por esses direitos não se esgotará nessa finalidade.

${ }^{41}$ Luís CARVAlHo FERnANDES, Lições de Direitos Reais cit., p. 426. 
unidos de facto é, portanto, uma concausa dos efeitos previstos no n. ${ }^{\circ} 1$ do art. $5 .^{\circ}$ da L.U.F..

Em terceiro lugar, para que o unido de facto sobrevivo possa ser encabeçado nos direitos referidos, é necessário, também, que o falecido fosse titular exclusivo do direito de propriedade sobre o imóvel em que se situava a casa de morada de família e dos bens móveis que integram o respetivo recheio ${ }^{42}$ ou que ambos os unidos de facto fossem titulares em compropriedade dos mesmos.

Em quarto lugar, para além dos elementos constitutivos acabados de enunciar ${ }^{43}$, no que respeita ao direito de habitação, o legislador vem prever, como facto impeditivo do reconhecimento de tal direito, a circunstância de o unido de facto sobrevivo ter "casa própria" 44 na

42 Não bastará, por isso, para o reconhecimento dos direitos previstos no art. $5 .^{\circ}$ da Lei $7 / 2001$, de 11 de maio na versão vigente, que o unido de facto falecido seja co-herdeiro da herança indivisa em que a casa de morada de família dos unidos de facto se integra. Como sabemos, o herdeiro de herança não partilhada é apenas titular de um direito de exigir a partilha dos bens integrantes do património hereditário e de, consequentemente, obter o preenchimento do respetivo quinhão hereditário através da adjudicação de bens da herança, ou do valor pecuniário correspondente à sua quota. Nesse sentido se pronunciou, o Supremo Tribunal de Justiça em Acórdão de 12 de maio de 2015 (in www.dgsi.pt), a propósito da proteção que era prevista no $n .^{\circ} 1$ do art. $4 .^{\circ}$ da redação original da Lei $7 / 2001$, de 11 de maio.

43 Para além dos elementos constitutivos assinalados, poderia autonomizar-se a necessidade do uso do recheio e a necessidade habitacional como requisitos de que depende o reconhecimento dos direitos referidos. Note-se, no entanto, que estes direitos não servem apenas uma finalidade "alimentar". Como referimos, eles são iluminados também por um propósito de garantir a continuidade do contexto familiar ao unido de facto sobrevivo. De qualquer modo, em homenagem a outros valores que merecem a tutela jurídica (nomeadamente aqueles que se encontram associados aos direitos dos titulares do direito de propriedade sobre o imóvel), em certos casos, o legislador vem destacar circunstâncias em que o direito de habitação não deve ser reconhecido (circunstâncias que se apresentam como factos impeditivos do reconhecimento do direito), ou, tendo-o sido, em que o mesmo deve extinguir-se (circunstâncias que consubstanciam factos extintivos do mesmo). É o que acontece nos números 5 e 6 do art. $5 .^{\circ}$ da L.U.F.

${ }^{44}$ Esta é a expressão empregada pelo legislador que abrangerá, quer a hipótese do unido de facto sobrevivo ser proprietário exclusivo do imóvel em questão, quer a hipótese de ele ser comproprietário do mesmo. Quid iuris se esses imóveis não constituem uma alternativa efetiva à satisfação das necessidades habitacionais do unido de facto sobrevivo que o direito de habitação (também) serve? Pensamos no caso de o imóvel estar arrendado, por força de um contrato celebrado antes da dissolução da união de facto e cuja vigência acordada ainda não se tenha extinguido. 
área do concelho da casa de morada da família ou ainda, quando esta se situe nos concelhos de Lisboa ou no Porto, nos concelhos limítrofes.

IV. Reunidos os pressupostos constitutivos sem que se concretize qualquer circunstância impeditiva, o direito de habitação sobre a casa de morada de família e o direito de uso do respetivo recheio serão, então, reconhecidos. Ora, para a definição da correspondente duração, o legislador vem consagrar um conjunto de regras ${ }^{45}$. Em duas delas, incorporam-se critérios legais de fixação configurados em termos gerais e abstratos, e, numa terceira, endossa-se ao julgador a sua concretização em termos casuísticos, à luz de juízos de equidade ${ }^{46}$.

Claro que podemos vislumbrar que, atento o disposto no ${ }^{\circ}{ }^{\circ} 6$ do art. $5 .^{\circ}$ da L.U.F., emergirá uma necessidade habitacional do senhorio que permitirá a denúncia do contrato de arrendamento (à luz do regime plasmado no Código Civil, vide o art. $1101 .^{\circ}$, al a) e o art. $1102 .^{\circ}$ ) o que, consequentemente, permitirá que, depois da sua concretização, o unido de facto se possa servir do imóvel desocupado para sua habitação. Não esqueçamos, no entanto, que, por um lado, a necessidade habitacional do senhorio pode não ser suficiente para o reconhecimento do direito de denúncia (pense-se, por exemplo, no disposto no ${ }^{\circ}{ }^{\circ} 10{ }^{\circ}$ do art. $1103 .{ }^{\circ}$ ) e que, entre o exercício do direito de denúncia e a concretização da devolução do espaço locado, pode mediar algum tempo. Também na situação de compropriedade, pode ocorrer que o unido de facto não possa usar, de imediato, a coisa, nomeadamente à luz de acordo anteriormente celebrado pelos comproprietários, nos termos da parte inicial do $n .^{\circ} 1$ do art. $1406 .^{\circ}$. Julgamos, então, que a aplicação do n. ${ }^{\circ} 6$ do art. 5 da L.U.F. ao caso concreto, com a devida consideração do elemento teleológico na operação interpretativa, poderá obviar à concretização de resultados injustificados, à luz da devida ponderação dos interesses em confronto.

45 Apesar da assinalada associação às necessidades do usuário e do morador usuário que poderia levar à conclusão de que a duração se mediria, casuisticamente, em função do período por que subsistissem aquelas necessidades. Segundo ANTUNES VARELA e PIRES DE LIMA, as necessidades pessoais e familiares do titular do direito de uso e do direito de habitação seriam apenas a medida do conteúdo do direito e já não "condição de validade ou manutenção do direito". In Código Civil Anotado cit., p. 546. Diversamente, para Luís CARVALHO FERNANDES, atendendo à circunscrição "finalista" do conteúdo dos direitos, a verificação de cessação das necessidades do respeito titular ditará a sua extinção. Lições de Direitos Reais cit., p. 427. A associação entre a duração do direito de habitação da casa de morada de família e as necessidades habitacionais do unido de facto sobrevivo encontra-se, hoje, subjacente à previsão normativa dos nos números 5 e 6 do art. $5 .^{\circ}$ da LUF.

46 Sublinhe-se que não pode ser diminuída por vontade dos particulares a duração dos direitos que resulta da aplicação destas regras legais. Repare-se que na redação anterior, atendendo à natureza dispositiva dos direitos, o proprietário da 
Assim, no n. ${ }^{\circ} 1$ do art. $5 .^{\circ}$ da L.U.F., fixa-se em cinco anos aquele que é, em princípio, o seu intervalo temporal mínimo de duração que, no entanto, é alargado, nos termos do n. ${ }^{\circ} 2$ do mesmo artigo, sempre que a relação de união de facto se tenha prolongado por mais de 5 anos. Nesses casos, a duração dos direitos coincidirá com a duração que aquela relação tenha, em concreto, alcançado. Assim, a título ilustrativo, na circunstância de a relação se ter prolongado por 15, 20 ou 30 anos, os direitos em análise vigorarão por idêntico período de tempo de 15, 20 e 30 anos, respetivamente.

A estas duas regras, vem, no entanto, juntar-se outra (formulada no.$^{\circ} 4$ do art. 5..$^{\circ}$ da L.U.F.) que, a título excecional, permite estender, por razões de equidade, os intervalos temporais referidos. Esta prorrogação pressupõe uma ponderação judicial, em que o tribunal atenderá às especificidades do caso concreto, considerando, nomeadamente, os factos que o legislador tem a preocupação de enunciar, exemplificativamente, no mesmo preceito - os cuidados dispensados pelo unido de facto sobrevivo ao companheiro falecido ou a familiares deste, e a especial carência em que aquele, por qualquer causa, se encontre. Pontificarão, aqui, a consideração de motivos de "carácter humanitário" e o reconhecimento de situações "dedicação pessoal" 47 . Intervirão, pois, nesta ponderação, finalidades assistenciais de necessidades atuais e compensatórias de comportamentos pretéritos no seio da relação de comunhão existencial que a união de facto traduz e que nem sempre se esgota no círculo formado pelos dois companheiros.

V. Por fim, cumpre referir que os direitos podem extinguir-se antes de se esgotar o período por que, em princípio, vigorariam, em virtude da ocorrência de circunstâncias que consubstanciam

casa poderia por disposição testamentária, não só excluir o direito, mas também limitar-lhe o período de vigência.

47 In Notas sobre a Lei . $^{\circ}$ 23/2010, de 30 de agosto (Alteração à Lei das Uniões de facto) cit., p. 145. 
causas extintivas dos mesmos ${ }^{48}$. Assim, por um lado, a factualidade prevista no n. 6 do art. 5 da L.U.F. como facto impeditivo do reconhecimento do direito real de habitação, poderá, em caso de superveniência após o momento da constituição do mesmo, ditar a sua extinção. Por outro lado, nos termos do n. 5 do mesmo artigo, a falta de habitação no imóvel por mais de um ano - ressalvada a hipótese de tal se ficar a dever a um motivo de força maior, como acontecerá, por exemplo, se o titular do direito se encontrar doente com necessidade de internamento em estabelecimento hospitalar importará a cessação, por caducidade, do direito de habitação da casa e do direito de uso do respetivo recheio ${ }^{49}$, ressalvada a hipótese de a mesma se ficar a dever a um motivo de força maior. Será o caso, por exemplo, de o titular do direito se encontrar doente com necessidade de internamento em estabelecimento hospitalar.

b) Direito de arrendamento do imóvel

I. Uma vez esgotado o período por que o unido de facto sobrevivo beneficiou do direito real de habitação nos termos acabados de enunciar, não é certo que o mesmo tenha que abandonar, de imediato, o imóvel. Na verdade, à luz do n. ${ }^{\circ} 7$ do art. 5. ${ }^{\circ}$ da L.U.F., é-lhe reconhecido o direito de permanecer nesse espaço na qualidade de arrendatário, nas condições gerais do mercado, e também o direito de aí continuar a habitar, até ao momento da celebração do correspondente contrato.

Note-se que não se trata, como se encontrava previsto na Lei 135/99, de 28 de agosto, de outorgar ao unido de facto sobrevivo

${ }^{48}$ A entrada em vigor da Lei $n .^{\circ} 23 / 2010$, de 30 de agosto suscitou problemas relativo à sucessão da lei no tempo, nomeadamente quanto à aplicação do regime previsto nos números 5 e 6 do art. $5 .^{\circ}$ relativo à proteção da casa de morada de família.

49 Trata-se de uma causa de extinção idêntica à prevista para os direitos reconhecidos ao cônjuge sobrevivo, nos termos do n. ${ }^{\circ} 2$ do art. $2103 .^{\circ}$-A. 
um direito de preferência relativamente a um eventual contrato de arrendamento do imóvel que o proprietário decidisse entretanto celebrar com terceiro ${ }^{50}$. A celebração do contrato de arrendamento é, agora, imposta a este último, a menos que o mesmo satisfaça os requisitos legalmente exigidos para a denúncia, pelo senhorio, do contrato de arrendamento para habitação ${ }^{51}$. Assim, não se verificando

50 O reconhecimento (legal ou convencional) de um direito de preferência a alguém não importa que a pessoa obrigada a dar preferência esteja vinculada à celebração de um contrato da espécie daquele a que a preferência respeita. $O$ obrigado à preferência conserva a liberdade de decidir contratar ou não contratar. Se decidir fazê-lo e se, uma vez acertado o teor do contrato com um terceiro, o preferente quiser celebrar o contrato "tanto por tanto", é que se corporiza o dever de celebrar o negócio com o preferente. No âmbito da relação de arrendamento urbano nos termos da alínea b) do $n .{ }^{\circ} 1$ do art. $1091 .^{\circ}$ do C.C., encontra-se previsto o direito de preferência do arrendatário relativamente à celebração de um novo contrato de arrendamento nos casos de caducidade do seu contrato por ter cessado o direito ou terem findado os poderes legais de administração com base nos quais o contrato fora celebrado.

51 Aplicando-se, mutatis mutandis, o regime dos art. $1101 .^{\circ}$ e ss ou apenas o do art. $1102 .^{\circ}$ do C.C.? Que significado deve ser atribuído à expressão "os requisitos legalmente estabelecidos para a denúncia do contrato de arrendamento para habitação, pelos senhorios, com as devidas adaptações"? Referir-se-á o inciso "para habitação" à finalidade do contrato de arrendamento e, portanto, na sua utilização irá contida uma referência aos contratos para os quais se previu um regime especial constante dos artigos $1092 .^{\circ}$ e ss do C.C. que compõem a subsecção sob a epígrafe "Disposições especiais do arrendamento para habitação"? Ou a fórmula usada pelo legislador remeterá apenas para a hipótese prevista na al. a) do art. $1101 .^{\circ}$ - denúncia do contrato de arrendamento para habitação do senhorio? FRANÇA PITÃo, sem questionar um outro sentido, na sua exposição envereda por este segundo entendimento. Vide Uniões de facto e Economia comum cit., 3. ${ }^{a}$ ed., 2011, pp. 213 e 216. Não nos parece, no entanto, que seja o único entendimento conjeturável, tendendo até para considerar que a referência legal respeita às 3 espécies de denúncia, pelo senhorio, do contrato de arrendamento para habitação. Pendemos para essa interpretação, considerando, desde logo, a colocação do inciso "pelo senhorio" entre vírgulas do que parece extrair-se uma associação dessa expressão à autoria da denúncia para a extremar da denúncia pelo arrendatário prevista no art. $1100 .^{\circ}$ do Código Civil. Ademais, se a expressão pretendesse significar a causa fundamentadora da denúncia com a necessidade habitacional do senhorio, deveria ser "para habitação do senhorio" (é, aliás, essa a formulação adotada pelo legislador no corpo do art. $1102 .^{\circ}$ ). Sendo assim, a possibilidade de denúncia do contrato de arrendamento de habitação pelo senhorio pode ser justificada com base numa das causas previstas nas alíneas a) (necessidade de habitação pelo senhorio ou pelos seus descendentes em $1^{\circ}$ grau) ou b) (para demolição ou realização de obra de remodelação ou restauro profundos que obriguem à desocupação do locado) do n. ${ }^{\circ} 1$ do art. $1101 .^{\circ}$ ou mesmo injustificada nos termos da al. c). Destaque-se que, entre outros pressupostos, na hipótese de denúncia por necessidade habitacional, 
qualquer das hipóteses previstas para esse efeito, o titular do direito de propriedade sobre o imóvel encontra-se vinculado à celebração do contrato de arrendamento. Os termos do mesmo devem, em princípio, configurar-se por negociação das partes, à luz das condições gerais do mercado. Na ausência de acordo, o tribunal pode ser chamado a intervir para definir os termos contratuais, após audição dos interessados (n. 8 do art. $5 .^{\circ}$ da L.U.F.). Ademais no ínterim, enquanto o contrato não se encontrar celebrado, o unido de facto pode permanecer no imóvel, com base no direito pessoal de gozo legalmente previsto na parte final do $\mathrm{n} .^{\circ} 7$ do art. $5 .^{\circ}$ da L.U.F., sem que lhe subjaza outro título (o unido de facto sobrevivo já não é

o proprietário do imóvel tem que proceder ao pagamento do montante equivalente a um ano de renda (art. $1102 .^{\circ},{ }^{\circ}{ }^{\circ} 1$ ) e, na hipótese de denúncia para demolição ou realização de obra, terá que, em alternativa, pagar valor idêntico ou garantir o realojamento do arrendatário em condições análogas às que este já detinha, quer quanto ao local quer quanto ao valor da renda e encargos (n. ${ }^{\circ} 6$ do art. $1103 .^{\circ}$ ). Em qualquer dos casos, o proprietário do imóvel, para impedir a celebração do contrato por invocação de uma dessas causas, deve ainda cumprir um dever de comunicação ao titular do direito de habitação com uma antecedência não inferior a seis meses sobre a data pretendida para a desocupação e da qual conste de forma expressa, sob pena de ineficácia, o fundamento da denúncia $\left(n .^{\circ} 1\right.$ do art. $\left.1103 .^{\circ}\right)$. Ao lado da possibilidade de denúncia justificada, existe ainda a faculdade de denúncia injustificada, mediante comunicação ao arrendatário com antecedência não inferior a dois anos sobre a data em que pretenda a cessação, nos termos da al. c) do art. 1101..$^{\circ}$. Ora, se não se verificar o circunstancialismo que permita denunciar o contrato nos termos das al. a) ou b) do art. $1101 .^{\circ}$, poderá o proprietário lançar mão da denúncia prevista na al. c). Nesse caso, o único requisito é o de uma comunicação, com a antecedência mínima de dois anos, pelo proprietário da vontade de não celebrar o contrato de arrendamento para que ele não se celebre. Atentos os requisitos temporais que, em qualquer das hipóteses, têm que ser observados, julgamos que o legislador pressupôs que a comunicação ocorreria ainda durante o período em que vigora o direito real de habitação, sob pena de o direito à celebração do contrato de arrendamento se constituir na esfera jurídica do unido de facto sobrevivo e poder ser oposto ao titular do imóvel. Quid iuris, se a comunicação não for feita com a necessária antecedência durante o período de vigência do direito de habitação? Poderá o unido de facto permanecer no imóvel durante o período em falta para perfazer o intervalo temporal requerido, aí residindo sem título (como na hipótese que descreveremos, de imediato, em texto, já que já não é titular de um direito real de habitação e não é - nem, neste caso, virá a ser - arrendatário)? Com uma resposta afirmativa, os interesses do unido de facto não seriam desguarnecidos, na medida em que haveria sempre que respeitar os requisitos de comunicação antecipada da não celebração do contrato e a letra da lei não exclui essa possibilidade. 
usuário morador e ainda não é arrendatário), que não a autorização legal aí concedida para o efeito.

II. A propósito deste mecanismo de tutela do unido de facto sobrevivo, subsistem alguns pontos nebulosos que não ficam esclarecidos pela formulação legalmente utilizada para o enunciar. Uma das questões carecidas de resposta surge quando se indaga se o direito à celebração do contrato de arrendamento respeita apenas ao imóvel ou ao imóvel e ao recheio ${ }^{52}$. A favor da segunda solução - que a letra da lei, apesar de não favorecer, não obstaculiza inequivocamente - podem chamar-se a colação, à luz de um raciocínio que faz apelo aos elementos interpretativos teleológico e sistemático, a consideração de que os direitos agora consagrados aparecem como um prolongamento de uma proteção do ambiente familiar que até aí se apresentou unitária, abrangendo as duas componentes - imobiliária e mobiliária - do mesmo. De qualquer modo, a letra do artigo parece apontar em sentido oposto ${ }^{53}$, confortando o entendimento de que a imposição da celebração do contrato de arrendamento nos termos referidos respeitará apenas ao imóvel ${ }^{54}$. Julgamos, aliás, que, se o legislador pretendesse acolher solução diversa, se teria expressado de forma diferente, traduzindo mais fielmente o seu pensamento, como o fez nos números anteriores em que, querendo referir-se às duas componentes da proteção, usou fórmulas legais que o esclareciam, remetendo claramente para o binómio protegido. Respeitando o arrendamento apenas ao imóvel,

52 O legislador contempla a hipótese de locação de um imóvel mobilado no art. $1065 .^{\circ}$ do C. C..

53 O artigo reza assim: "Esgotado o prazo em que beneficiou do direito de habitação" e "o membro sobrevivo tem o direito de permanecer no imóvel". Os sublinhados são nossos.

$54 \mathrm{O}$ facto de nos parecer que a imposição legal do dever de celebrar o contrato respeita apenas ao imóvel, não significa, evidentemente, que o contrato que venha a ser celebrado por força do . $^{\circ} 7$ do art. $5 .^{\circ}$ da L.U.F. não possa abranger também o recheio. Tratar-se-á, aí, no entanto, de uma estipulação que brotará do exercício da autonomia privada das partes, não sendo imposta pelo legislador. 
tal significará, então, que, findo o direito de uso, o(s) proprietário(s) dos bens móveis que compõem o recheio daquela que foi a casa de morada de família, os poderá(ão) alienar sem que o adquirente dos mesmos veja a sua posição jurídica dominial limitada por qualquer encargo que sobre eles impenda.

III. E, aqui, nos aparece uma outra questão que é a de saber como se articulam os direitos previstos no $n .^{\circ} 755$ do art. $5 .^{\circ}$ da L.U.F. com os direitos que um terceiro adquira sobre o imóvel, em virtude de uma eventual alienação do mesmo56.

Cumpre advertir que não nos referimos à hipótese de o contrato de arrendamento já ter sido celebrado, ao abrigo do disposto no citado preceito, antes da alienação do imóvel. Nesse caso, o unido de facto pode opor a sua posição contratual de arrendatário ao adquirente, à luz da regra "emptio non tollit locatum" vertida no art. 1057. ${ }^{\circ}$ do C.C.. Assim, o novo proprietário do imóvel sucede, nos direitos e nas obrigações emergentes do contrato de locação para o locador, tendo o locatário o direito a perseguir a coisa onde quer que ela se encontre ${ }^{57}$.

Diversamente, o circunstancialismo que consideramos, neste ponto, é o de o contrato de arrendamento ainda não ter sido celebrado quando se efetiva a alienação ao terceiro. Os deveres correlativos

55 A dúvida surge a propósito dos direitos previstos neste número. O direito de habitação entretanto extinguido, como direito real (de gozo) que é, está dotado do atributo da sequela, acompanhando o bem para onde quer que ele vá, podendo assim o unido de facto sobrevivo opô-lo ao terceiro adquirente.

56 Não nos reportamos, aqui, à transmissão inerente à aquisição sucessória pelos herdeiros, para composição da sua quota hereditária, ou pelos legatários, em cumprimento de uma disposição testamentária ou de um pacto sucessório, nas situações em que estes pactos são permitidos. Referimo-nos, portanto, a uma transmissão posterior à que ocorre no âmbito do fenómeno sucessório.

57 Gozando de um atributo de sequela traduzido num fenómeno idêntico ao da inerência, esta característica do direito do arrendatário, que o aproximará dos direitos reais, apresenta-se como um dos argumentos que sustentam a conceção realista do mesmo. Vide, por todos, LUís MENEZES LEITÃO, Direito das Obrigações, Vol. I, Introdução. Da Constituição das Obrigações, 11. ${ }^{a}$ edição, 2014, Almedina, pp. 96 e ss. 
aos direitos outorgados ao companheiro sobrevivo por força do n. ${ }^{\circ}$ 7 do art. 5. ${ }^{\circ}$ da L.U.F. impor-se-ão ao terceiro adquirente? Tais direitos acompanham o bem, como o acompanhariam, por um lado, o direito real de habitação no caso de ainda não ter cessado ao tempo da alienação e, por outro lado, a posição de arrendatário no caso de o contrato de arrendamento já ter sido celebrado? A situação que ora consideramos distancia-se dessas duas. Não tendo os direitos em questão natureza real $^{58}$ e inexistindo uma norma que precipuamente se refira à articulação entre o direito previsto no n. 7 do art. 5. ${ }^{\circ}$ da L.U.F. e a eventual transmissão do direito de propriedade sobre o imóvel a terceiro, quid iuris? Julgamos que a solução da oponibilidade a terceiro é aquela que parece decorrer mais diretamente do preceituado na norma, ao não serem definidos os sujeitos vinculados pelos deveres correlativos aos direitos aí previstos. Tais deveres impor-se-ão, então, àqueles que, no momento em que os direitos surjam na esfera jurídica do unido de facto, sejam titulares do direito de propriedade sobre o imóvel, independentemente da eventual cadeia de transmissão entretanto ocorrida. O legislador não distingue e não vislumbramos sólidas razões para o intérprete distinguir, à luz dos instrumentos de que pode lançar mão na tarefa interpretativa59. Ademais sublinhe-se que a cognoscibilidade, pelo terceiro adquirente, da imposição in casu dos citados deveres é garantida, por força da publicidade assegurada pelo registo predial do

58 Atente-se no princípio da tipicidade previsto no art. $1306 .^{\circ}$ do Código Civil. Estaremos perante um direito de fonte legal tendente à aquisição da posição contratual de arrendatário.

59 Não encontrámos, nos elementos interpretativos, apoio suficiente para ensaiar uma interpretação restritiva que limitasse o efeito previsto no n. ${ }^{\circ} 7$ do art. $5 .^{\circ}$ aos adquirentes do imóvel no âmbito do fenómeno sucessório. Julgamos, portanto, que tal limitação pressuporia uma intervenção legislativa que consagrasse essa solução. Sabemos, de qualquer modo, que, contra tal alteração, militará o perigo de haver uma alienação só com o intuito de impedir a concretização da celebração do contrato de arrendamento. Claro que, numa tal hipótese, o regime geral, nomeadamente dos vícios de vontade, ofereceria uma resposta jurídica aos casos que a merecessem. 
direito real de habitação ${ }^{60}$ que antecede o surgimento dos deveres previstos no n. ${ }^{\circ} 5$ do art. $7 .^{\circ}$ da L.U.F. e em virtude desta previsão legal, de cujo conhecimento ninguém é escusado (art. 6. ${ }^{\circ}$ do C.C.) ${ }^{61}$.

Assim, julgamos que, também, o terceiro adquirente estará vinculado pelos deveres legalmente impostos no n. 7 do art. $5 .^{\circ}$ da L.U.F., devendo celebrar o contrato, a menos que, quanto a ele, se verifiquem os pressupostos de que a lei faz depender a denúncia, pelo senhorio, do contrato de arrendamento para habitação ${ }^{62}$.

c) Direito de preferência em caso de alienação do imóvel

I. Finalmente, prevê-se, no n. ${ }^{\circ} 8$ do art. $5 .^{\circ}$ da L.U.F., em favor do unido de facto sobrevivo, um direito de preferência em caso de alienação do imóvel onde se situava a casa de morada de família. É, aqui, inequívoca a dissociação - que julgamos concretizada, como referimos supra, também quanto ao direito analisado na subsecção anterior - da proteção das componentes mobiliária e imobiliária do

$60 \mathrm{O}$ direito real de habitação sobre prédio urbano está sujeito a registo nos termos do art. $2 .^{\circ},{ }^{\circ}{ }^{\circ} 1$ al. a) do Código de Registo Predial, devendo o extrato da inscrição conter a menção à causa do direito, ex vi do art. $95 .^{\circ}$, n. $^{\circ} 1$ al. a) do mesmo Código.

${ }^{61}$ No caso de o alienante prestar informações erradas, no âmbito do processo de negociação, que consubstanciem a violação culposa dos deveres impostos pela boa-fé, poderá o adquirente lançar mão do mecanismo previsto no art. $227 .{ }^{\circ}$ do Código Civil.

62 Tratar-se-á das situações previstas no art. $1101 .^{\circ}$ e ss do C.C., a que já nos referimos na nota 51. Pode perguntar-se se a comunicação de não celebração do contrato de arrendamento feita pelo anterior adquirente, com base num dos fundamentos (de denúncia) previstos nas alíneas do art. $1101 .^{\circ}$, pode afastar os direitos do companheiro sobrevivo previsto no $\mathrm{n} .{ }^{\circ} 7$ do art. $5 .^{\circ}$ também em relação ao novo adquirente. Atendendo a que as situações das al. a) e b) do art. $1101 .^{\circ}$ pressupõem uma causa que tem, aliás, que ser comunicada expressamente ao unido de facto sobrevivo, duvidamos que a sua eficácia se possa estender por forma a excluir os deveres (legais) do novo adquirente. Ademais, na hipótese da al. a), tal é inviabilizado pela natureza pessoal do fundamento da necessidade habitacional relativo às pessoas enunciadas no preceito e ao dever previsto no n. ${ }^{\circ} 5$ do art. $1103 .^{\circ}$, cujo incumprimento é sancionado nos termos do $n .^{\circ} 9$ do mesmo artigo. Diversa é a hipótese prevista na al. c) do art. $1101 .^{\circ}$ que é imotivada, pelo que, quanto a ela, apenas se acautelam os interesses do unido de facto sobrevivo, relativamente ao conhecimento antecipado de que terá que abandonar o imóvel. 
contexto familiar, já que o direito de preferência concerne apenas à alienação do imóvel onde se encontrava sediada a vida familiar dos unidos de facto antes da morte do respetivo proprietário e não à alienação dos bens móveis (considerados individualmente ou tomados, no seu conjunto, como universalidade de facto) que compõem o respetivo recheio.

II. Feita esta precisão, importará considerar sobre que atos incidirá o direito de preferência consagrado a favor do unido de facto. O legislador refere-se, agora, à alienação ${ }^{63}$ do imóvel, podendo esta ocorrer com base em múltiplos títulos de natureza diversa ${ }^{64}$. Assim, e ilustrativamente, o proprietário aliena o imóvel quando o vende, quando o doa ou ainda quando o dá em dação em cumprimento. Terá o unido de facto direito a preferir relativamente a qualquer um destes atos translativos do direito real? A delimitação do perímetro do direito de preferência consagrado no n. 9 do art. $5 .^{\circ}$ da L.U.F. e, consequentemente, a resposta a esta questão encontra-se através da consideração dos limites da figura do direito de preferência que é apenas compatível com atos onerosos que não tenham caráter intuitu personae $^{65}$. Nessa medida, o unido de facto poderá preferir relativamente à situação de compra e venda, e de dação em cumprimento, mas já não quanto à hipótese de o imóvel ser alienado por doação.

$63 \mathrm{O}$ direito de preferência respeitava, na Lei 135/99, de 28 de agosto, à venda e ao arrendamento (art. $4 .^{\circ},{ }^{\circ}{ }^{\circ} 1$, in fine) do imóvel e, na versão inicial da Lei $7 / 2001$, de 11 de maio, à venda do mesmo (art. $4 .^{\circ}$, n. ${ }^{\circ} 1$, parte final).

${ }^{64}$ Repare-se que, em regra, nos casos de previsão legal dos direitos de preferência, o legislador é mais preciso na enunciação dos atos, por ela, abrangidos. Veja-se, a título ilustrativo, que, no âmbito da relação de arrendamento urbano, no âmbito da compropriedade, ou do fenómeno sucessório, o direito de preferência reconhecido ao arrendatário, aos comproprietários e aos co-herdeiros respeita à compra e venda e à dação em cumprimento, respetivamente, do local arrendado (al. a) do n. ${ }^{\circ} 1$ do art. $1091 .^{\circ}$ do C. C.), da quota do bem detido em compropriedade (n. ${ }^{\circ} 1$ do art. $1409 .^{\circ}$ do C.C.) e do quinhão hereditário (art. $2130 .^{\circ},{ }^{\circ}{ }^{\circ} 1$ do C.C.).

65 LUís MENEZES LEITÃo, Direito das Obrigações cit., p. 223. Note-se, no entanto, que o direito de preferência não se estenderá ao contrato de troca, apesar da sua natureza onerosa. Veja-se RIBEIRO DE FARIA, Direito das Obrigações, Vol. I, Coimbra, Almedina, 1990, p. 285. 
III. A titularidade do direito de preferência respeitará a todo o período em que o unido de facto sobrevivo habitar o imóvel "a qualquer título" (art. 5. ${ }^{\circ}, .^{\circ} 9$ in fine). Assim, ele encontra-se encabeçado no direito, ininterruptamente, enquanto é morador-usuário, enquanto é arrendatário, no caso de se concretizar a celebração do contrato de arrendamento prevista no n. $^{\circ} 7$ do art. 5 da L.U.F. e, ainda, durante o segmento temporal que medeia entre os períodos em que está investido nessas duas qualidades e, em que, portanto, habita o imóvel, sem (outro) título ${ }^{66}$.

Note-se que a inclusão, na previsão do.$^{\circ} 9$ do art. $5 .^{\circ}$ da L.U.F., da titularidade do direito de preferência na veste de arrendatário não é despicienda, apesar da previsão do art. $19010^{\circ}$ do Código Civil que atribui ao arrendatário de prédio urbano o direito de preferência na compra e venda e na dação em cumprimento do local arrendado. $\mathrm{Na}$ verdade, o legislador exige uma vigência mínima, por 3 anos, do contrato de arrendamento para reconhecer o direito de preferência ao arrendatário. Ora, no caso de contrato celebrado com o unido de facto sobrevivo, ao abrigo do art. 5. da L.U.F., este, na qualidade de arrendatário, será titular do direito de preferência, durante toda a constância da relação locatícia, sem necessidade de um decurso mínimo da mesma para que o direito se consolide na sua esfera jurídica.

IV. Assim, em qualquer momento do período em que o unido de facto sobrevivo resida no imóvel, se o proprietário do mesmo ${ }^{67}$ decidir aliená-lo (onerosamente), deve comunicar àquele, a intenção de alienação, efetuando uma notificação para preferência onde de-

${ }^{66}$ Como já referimos, o título fundamentador da sua permanência no imóvel é a própria lei.

67 Que pode já não estar integrado no património hereditário, nem sequer no património de um dos sucessíveis mortis causa do falecido, dado que pode ter ocorrido, entretanto, uma alienação do imóvel. Veja-se o que dissemos a este propósito supra quando considerámos os efeitos da transmissão do imóvel sobre os deveres previstos no $n .^{\circ} 7$ do art. $5 .^{\circ}$ da L.U.F.. 
vem ser enunciadas as cláusulas do contrato a celebrar com terceiro (art. $416 .^{\circ}$ do C.C.), e, segundo parte da doutrina e da jurisprudência, outros elementos que possam ser essenciais para determinar a vontade de preferir ${ }^{68}$. Na hipótese que consideramos, avultará a questão controvertida de saber se a identidade de terceiro deverá ser incluída na notificação para preferência. Parece-nos que a resposta deve ser afirmativa ${ }^{69}$, dado que é uma informação que reveste um interesse particular na constelação fáctica considerada. Na verdade, o companheiro, no caso de não exercer o direito de preferência, poderá, apesar da alienação do imóvel, permanecer no mesmo, ao abrigo do direito real de habitação, da posição de arrendatário ou, ainda, na situação prevista na parte final do $n .^{\circ} 7$ do art. $5 .^{\circ}$ da L.U.F., entretecendo-se, portanto, uma relação jurídica entre ele e o novo proprietário do prédio urbano. É, portanto, uma informação relevante para o preferente formar a sua vontade sobre a decisão de preferir ou não preferir.

V. Uma última palavra, para sublinhar que, tratando-se de uma preferência de fonte legal, tal se refletirá, desde $\operatorname{logo}^{70}$, nas consequências associadas ao seu incumprimento por celebração, com terceiro, de negócio com preterição indevida do direito do unido de facto preferente relativamente a tal negócio. Assim, em caso de violação do direito previsto no . $^{\circ} 9$ do art. 5..$^{\circ}$ da L.U.F., o companheiro sobrevivo pode recorrer à ação de preferência, nos termos do art. $14100^{\circ}$ do C.C., para se sub-rogar na posição jurídica do adquirente,

${ }^{68} \mathrm{Na}$ doutrina e na jurisprudência inexiste unanimidade quanto aos elementos que devem ser incluídos na notificação para a mesma ser eficaz e, consequentemente, poder ditar, ex vi do $\mathrm{n}^{\circ} 2$ do art. $416 .^{\circ}$, o início da contagem do prazo para o exercício do direito do preferente. Veja-se, por todos, AgOsTinHo GUEDES, O exercício do direito de preferência, Universidade Católica Editora, 2006, pp. 457 e ss.

69 No mesmo sentido, FranÇA PITÃo, in Uniões de facto e Economia Comum cit., 2. ${ }^{\mathrm{a}}$ ed, p. 249.

70 Por outro lado, a natureza legal, relevará, também, na graduação de que o mesmo beneficiará em caso de concurso com preferências de natureza convencional (ex vi do art. $422 .^{\circ}$ do C.C.). 
com efeito retroativo, como se o ato de alienação tivesse, portanto, sido celebrado $a b$ initio entre ele e o alienante.

\subsection{A imposição da proteção e a insusceptibilidade de afastamento por vontade do de cuius - o estranho caso de um legatário legal forçoso não legitimário?}

I. Concluído o breve excurso reflexivo sobre o regime consagrado nos números 1 a 9 do art. 5. ${ }^{\circ}$ da L.U.F., constatámos a ocorrência do reforço da posição jurídica do companheiro sobrevivo, em caso de dissolução da união de facto por morte de um dos seus membros, relativamente ao contexto imobiliário (a casa de morada de família) e mobiliário (o correspondente recheio) em que se desenvolveu a vivência em condições análogas às dos cônjuges, quando o falecido seja proprietário dos bens que compunham tal contexto. Como vimos, o legislador prevê, para o efeito, uma cascata de direitos que se articulam num complexo intrincado que proporciona ao companheiro sobrevivo uma tutela da continuidade do ambiente familiar que, agora, pode estender-se por um extenso intervalo de tempo.

No núcleo da proteção prevista, encontra-se o direito de habitação sobre a casa de morada de família, hoje associado ao direito de uso do respetivo recheio, que, com a Lei 23/2010, de 30 de agosto, para além de conquistar, nos termos dos números 2 e 4 do art. $5 .^{\circ}$ da L.U.F., extensão temporal, sai robustecido pela eliminação da sua natureza dispositiva. Na verdade, em 2010, o legislador suprime a enunciação das exceções ao reconhecimento do direito (hoje um binómio de direitos) que previa no n. 2 do art. $4 .^{\circ}$ da redação inicial da Lei 7/2001, de 11 de maio $^{71}$, deixando, portanto, de ser possível o afastamento da aplicação do regime legal por vontade do unido de facto proprietário dos bens, através de disposição testamentária

${ }^{71} \mathrm{E}$ que, como vimos, também se vertiam no art. $4 .^{\circ}, \mathrm{n}^{\circ} 1$ da Lei $135 / 99$, de 28 de agosto, embora com uma diferente configuração. 
em contrário ${ }^{72}$. A possibilidade de derrogação voluntária que anteriormente se previa enfraquecia a proteção legalmente consagrada, colocando-a na dependência direta da vontade do titular da casa de morada de família que podia, portanto, suprimir ad nutum a sua aplicação. Quaisquer que fossem as razões que inspirassem o companheiro proprietário (que não tinham sequer que ser apresentadas), a sua vontade prevalecia sobre o regime legalmente configurado, no que ia contida uma fragilização acentuada da tutela que, através dele, se procurava prosseguir. Hoje, os efeitos jurídicos previstos no n. ${ }^{\circ} 1$ do art. 5. ${ }^{\circ}$ da L.U.F. impõem-se, então, à vontade do de cuius, sendo, nessa medida, imperativos.

II. Deixa, portanto, de se acomodar a qualificação que lhe era dada, sob a vigência da redação inicial da Lei 7/2001, de 11 de maio e que levava vários Autores portugueses a apodar o unido de facto sobrevivo de legatário legítimo do direito de habitação, por 5 anos, da casa de morada de família integrada no património hereditário do seu companheiro falecido ${ }^{73}$.

Nesse sentido, os Professores Pereira Coelho e Guilherme de Oliveira, referiam-se, a esse propósito, a uma "designação suces-

\footnotetext{
72 Limitação que, também, se aplicará aos pactos sucessórios, nos casos em que eles são excecionalmente admitidos (artigos $1700 .^{\circ}$ e ss e art. $2028 .^{\circ}$ do C.C.).

73 Assim, referindo-se à posição jurídica do unido de facto à luz do art. 4. ${ }^{\circ}$, números 1 e 2 da redação inicial da Lei 7/2001, de 11 de maio, PEREIRA COELHO e GUILHERME OLIVEIRA qualificavam-na como "legado legítimo". Curso de Direito da Família cit., p. 84. Reportando-se à mesma disposição, GUILHERME DE OLIVEIRA claramente dizia "A proteção era encarada tecnicamente como um legado legítimo e, portanto, cedia perante uma disposição testamentária incompatível, segundo a hierarquia das designações sucessórias". In Notas sobre a Lei n. ${ }^{\circ} 23 / 2010$, de 30 de agosto (Alteração à Lei das Uniões de facto) cit., p. 146. No mesmo sentido, LUís CARVAlHO FERNANDES, Lições de Direitos Reais cit., p. 429. Também FrANÇA PITÃO, quanto à Lei 135/1999, de 28 de agosto, in União de Facto no Direito Português. A propósito da Lei n. ${ }^{\circ}$ 135/99, de 28/08, Coimbra, Almedina, 2000, pp. 160-161 e p. 168 , e, quanto à versão inicial da Lei $7 / 2001$, de 11 de maio, in Uniões de facto e Economia Comum, 2. ${ }^{a}$ ed. revista e atualizada, Coimbra, Almedina, 2006, p. 247. No que respeita à redação introduzida pela Lei 23/2010, de 30 de agosto, refere-se-lhe como legatário legal. In Uniões de facto e Economia Comum, $3 .^{a}$ ed. revista e atualizada, Coimbra, Almedina, 2011, pp. 213 e 214.
} 
sória" do unido de facto que, podendo ser afastada por disposição testamentária em contrário, ocupava "na hierarquia das designações sucessórias" um "lugar inferior ao da sucessão testamentária e da sucessão legitimária, nos termos gerais" 74 .

Cumprirá, então, refletir sobre as repercussões que a alteração de regime importou na natureza da posição jurídica do unido de facto sobrevivo como morador usuário da casa e agora também como usuário do respetivo recheio, por força da morte daquele com quem viveu em união de facto e que era proprietário dos bens sobre que incidem tais direitos. Vejamos, mais de perto, embora de forma breve, esta problemática.

III. Em primeiro lugar, consideremos a qualificação do companheiro sobrevivo, à luz do art. 5. ${ }^{\circ}$, n. 1 da L.U.F., como legatário. O acerto desta asserção pressuporá que possamos afirmar que tal sujeito se apresenta como sucessível mortis causa do falecido.

Como vimos, a morte é a concausa ${ }^{75}$ da produção dos efeitos previstos no n. ${ }^{\circ} 1$ do art. 5 da L.U.F., perfilando-se, portanto, os mesmos como efeitos legais mortis causa. Na verdade, é o legislador que associa à ocorrência da morte de um dos membros de uma união de facto eficaz, o reconhecimento ao companheiro sobrevivo dos direitos de habitação da casa de morada de família e de uso do respetivo recheio, no caso de os correspondentes bens integrarem o património hereditário. Assim, ainda que seja necessária a preexistência de uma relação de união de facto, julgamos que, na perspetiva da lei, a morte do unido de facto proprietário é configurada como uma das causas da aplicação do regime em questão.

Aceitando que assim é, deparamo-nos ainda com uma outra objeção à afirmação de que o mecanismo jurídico previsto no $n .^{\circ} 1$

\footnotetext{
${ }^{74}$ Curso de Direito da Família cit., p. 84.

75 RABindranath CAPELO DE SOUSA, Lições de Direito das Sucessões, Vol. I, $4{ }^{a}$ Ed. Renovada, Coimbra Editora, 2013 (reimpressão da $4{ }^{a}$ edição renovada de 2000), p. 25.
} 
do art. 5. ${ }^{\circ}$ da L.U.F. consubstancia um efeito sucessório. O obstáculo de que falamos advém da identificação - comum na doutrina portuguesa - da sucessão mortis causa com a ocorrência de um fenómeno de transmissão ${ }^{76}$ de direitos ${ }^{77}$, o que, por sua vez pressuporá a identidade ${ }^{78}$ do direito que é transmitido na esfera jurídica do transmitente e na do transmissário e, consequentemente, traduzirá a verificação de uma aquisição derivada translativa de direitos. Como consequência de tal conceção, a aquisição derivada constitutiva de

76 Sabemos que se discute a natureza do fenómeno sucessório mortis causa, procurando determinar se o mesmo se identifica com o conceito de transmissão. Discute-se, a esse propósito, se é uma situação de aquisição derivada (translativa) ou se é uma situação de modificação subjetiva em que há o subingresso dos sujeitos nas relações jurídicas de que o de cuius era titular. Sobre esta questão, vide PEREIRA COELHO, Direito das Sucessões (Lições ao curso de 1973-1974, actualizadas em face da legislação posterior), Coimbra, 1992, pp. 7 a 24. Este Autor, entendendo que "transmissão" e "sucessão" traduzem "duas perspetivas diferentes ou dois diferentes modos de consideração da mesma realidade", defende que a distinção entre os dois termos deve ser feita por permitir a compreensão da evolução histórica do fenómeno da sucessão e a distinção entre herdeiro e legatário (op. cit., pp. 20 a 23 ). Aliás, conclui que se usássemos linguagem de grande rigor, guardaríamos o termo sucessão para designar a sucessão por morte e, dentro desta, só para a sucessão universal, ou seja, a sucessão em benefício do herdeiro. Verdadeiramente, apenas este é sucessor, pois "só ele substitui o "de cuius" ou subingressa no lugar dele, como acontece na sucessão nos termos em que a caracterizámos: o comprador, o cessionário, o legatário são meros adquirentes”. Op. cit., p. 23.

77 A sucessão não abrange apenas posições jurídicas ativas, mas, atendendo ao objeto do presente trabalho, perspetivaremos, no nosso discurso, apenas a sucessão de direitos.

78 Assim, o conceito de sucessão incluiria no seu âmbito apenas a aquisição derivada translativa. No sentido de que a identidade entre o direito do sucessor e o do de cuius é um elemento constitutivo do conceito de sucessão, o que conduzirá à exclusão das aquisições derivadas constitutivas ou restitutivas do "sentido rigoroso" de sucessão, por falta daquela identidade, veja-se PEREIRA COELHO, Direito das Sucessões cit., pp 16 e 17. No mesmo sentido, CRISTINA DIAS, Lições de Direito das Sucessões, 2. ${ }^{a}$ edição, Coimbra, Almedina, 2012, pp. 27 a 28. CARLOS PAMPLONA CORTE-REAL também entende que as noções de transmissão e de aquisição derivada translativa são insuficientes para explicar algumas das situações jurídicas cobertas pelo fenómeno sucessório. Por isso, acaba por entender que o conceito de sucessão económica, de que falaremos infra, de GALVÃo TELLES é "realista, face ao casuísmo e heterogeneidade institucional do fenómeno sucessório", apesar de representar uma " "brecha” no rigor da sua construção dogmática da sucessão”. Curso do Direito das Sucessões, Lisboa, Quid iuris, 2012, pp. 27 a 29. 
direitos $^{79}$, como a que ocorre no caso vertente, ficaria arredada do fenómeno sucessório.

Não é, como se sabe, no entanto, uma objeção inultrapassável ${ }^{80}$. O labor doutrinal desenvolveu caminhos que permitem transpô-la e a própria lei fornece elementos que permitem sinalizá-los. A esse propósito, encontramos, entre nós, Galvão Telles que interpreta o requisito da identidade do direito transmitido como uma exigência que veda apenas a possibilidade de se operar um fenómeno sucessório em que o direito adquirido pelo sucessível seja maior que o direito de que o autor da sucessão dispunha ${ }^{81}$, construindo, a esse propósito, o conceito de sucessão económica ${ }^{82}$. Como exemplos,

79 PEREIRA COElho, Direito das Sucessões cit., pp. 16 a 18.

80 Aliás, a qualificação doutrinal da posição jurídica do unido de facto como legatário legítimo, à luz do regime inicial da Lei 7/2001, de 11 de maio é disso demonstrativo. Veja-se nota 73.

81 Galvão Telles, In Direito das Sucessões. Noções Fundamentais cit., pp. 43 e 44. "A identidade do direito não impede que este sofra alterações, e que a identidade do regime não é absoluta" (p. 43). "O adquirente não pode receber mais do que tinha o transmitente, mas pode receber menos". (p. 43). Assim, o Autor acrescenta que a configuração anterior do direito "é o máximo que o adquirente pode receber. Mas a aquisição poderá ficar aquém desse máximo, quantitativa e qualitativamente”. P. 44. O sublinhado é do Autor.

82 Galvão Telles, in Direito das Sucessões. Noções Fundamentais cit., p. pp. 84 e 85 . Por isso, não haveria uma inteira coincidência entre a transmissão e a sucessão, já que "percorrendo as normas do direito sucessório verificamos que elas assimilam aos casos de verdadeira e própria transmissão outros de diversa estrutura formal mas de equivalente significado prático". O Autor acrescenta, de seguida, que "as noções de sucessão ou transmissão e de direito sucessório aparecem assim distorcidas ou ampliadas pela aglutinação de outras matérias não correspondentes aos conceitos jurídicos puros". Como traço comum às situações que entram no domínio sucessório aparece "o de sucessão económica". "A lei parte da sucessão jurídica para chegar à sucessão económica. Esta, aliás, é também reconduzível a uma ideia jurídica, a de enriquecimento gratuito por morte". Assim, "nas malhas do direito sucessório, e sob o nome de sucessão desviado do seu genuíno significado lógico-jurídico, entram todos os casos em que por morte de alguém, e à custa do seu património, outrem alcança um enriquecimento sem ter de dar contrapartida. (...) $\mathrm{O}$ enriquecimento pode ser atribuído pela lei ou pelo de cuius, caso este em que se fala de liberalidade". O Autor acrescenta, generalizando essa terminologia, que, num caso, haveria "liberalidade voluntária" e, no outro, "liberalidade legal". Idem, p. 85. DIEZ PICAZO refere-se a uma "sucessão constitutiva". Lecciones de Derecho Civil, Vol. IV: Derecho de Sucesiones, Madrid, Tecnos, 1998, p. 14. 
aliás, da insuficiência do conceito da aquisição derivada translativa para caracterizar o fenómeno aquisitivo presente na sucessão mortis causa, o Autor apresenta, precisamente, os do chamamento (por deixa ou por disposição legal) de um sucessível a um direito de usufruto ou a um direito de uso e habitação ${ }^{83}$.

O próprio legislador o aceita, aliás, expressamente, ao admitir que a sucessão mortis causa respeite ao direito de usufruto sobre parte ou a totalidade da herança ${ }^{84}$, qualificando o respetivo sucessível como legatário (art. $20130 .^{\circ}$, n. $^{\circ} 4$ e $2258 .^{\circ}$ do C.C.). Ora, na medida em que o direito de usufruto (tal como o direito de uso e o direito de habitação) não existe enquanto tal na esfera jurídica do de cuius, trata-se de um chamamento sucessório que importará uma aquisição derivada constitutiva e, portanto, um desvio ao conceito de sucessão que se limite a compreender fenómenos de aquisição derivada translativa ${ }^{85}$.

83 GALVÃo TELLES, Direito das Sucessões. Noções Fundamentais cit., pp. 86 e 87.

84 Trata-se de uma possibilidade que se concretiza por ato de vontade do de cuius, dado que o nosso legislador não previu a atribuição, a nenhum sucessível, de um direito dessa espécie. No Código Civil de 1966, na versão original, nos termos do art. $2133 .^{\circ}$, atribuía-se ao cônjuge sobrevivo, na falta de descendentes, ascendentes, irmãos ou seus descendentes, o direito de usufruto vitalício da herança. Repare-se, ainda, que, no Anteprojeto da Parte do novo Código Civil relativa ao Direito das Sucessões da Autoria de INOCÊNCIO GALVÃo TELLES, se previa que a legítima do cônjuge - que se consagrava como sucessível legitimário ao lado dos ascendestes e dos descendentes (art. 152. ${ }^{\circ}$ ) - fosse constituída pelo direito de usufruto de metade da herança (art. $163 .^{\circ}$ do mesmo projeto). In Boletim do Ministério da Justiça, n. ${ }^{\circ}$ 54, março de 1956, pp. 19 e ss, em especial pp. 73 e 76.

85 PEReIRa COElHo refere-se, aliás, a esta objeção em nota 57, na p. 73, do seu Direito das Sucessões cit., aquando da qualificação do usufrutuário como herdeiro ou legatário (perfilhando a solução legal de o qualificar como legatário), mas não lhe dá grande valor, entendendo que se tratará de uma argumentação eivada de conceitualismo, remetendo, aliás, para as observações de GALVÃo TELLES. Este Autor, quando aborda a problemática da qualificação dos sucessíveis como herdeiros ou legatários inclui no elenco de hipóteses que consubstanciam chamamentos na qualidade de legatários as situações em que o sucessível "adquire um direito novo formado à custa de preexistente direito do de cuius, que sofre correlativa oneração ou limitação, como o usufruto de determinado bem". Direito das Sucessões. Noções Fundamentais cit., pp. 84 e 85. 
Admitindo, então, que o companheiro sobrevivo, como usuário e morador usuário nos termos do art. $5 .^{\circ}$, n. 1 da L.U.F, é um sucessível no sentido acabado de referir ${ }^{86}$, deverá ser integrado na categoria dos legatários ${ }^{87}$, já que o mesmo é chamado a adquirir direitos certos e determinados sobre bens, também eles, certos e determinados, ainda que, no caso do recheio da casa não estejam especificados $^{88}$. Pode, aliás, ser invocado, neste sentido, o disposto no já referido n. ${ }^{\circ} 4$ do art. $20300^{\circ}$ do C.C., considerando a qualificação que o legislador aí inclui relativamente ao usufrutuário de parte ou totalidade da herança ${ }^{89}$.

IV. Aceitando que é um legatário, constituirá, então, um exemplo de legatário legal ${ }^{90}$, já que o título em que assenta o chamamento do sucessível é a lei. O facto de o de cuius não poder arredar a aplicação dos efeitos previstos no n. ${ }^{\circ} 1$ do art. $5 .^{\circ}$ da L.U.F. impedirá a sua qualificação, à semelhança do que ocorria sob a égide da redação inicial da Lei 7/2001, de 11 de maio, como legatário legítimo. Na verdade, a sucessão legítima, caracteriza-se pela possibilidade do seu afastamento pela vontade do seu autor (art. 2027. ${ }^{\circ}$ ), o que, como vimos, não se verifica na hipótese vertente.

O de cuius não poderá derrogar a aplicação do regime descrito, não podendo, portanto, em simplesmente afastar essa aplicação, nem

86 O que permitirá, por exemplo, aplicar o regime das indignidades sucessórias previstas no art. $2034 .^{\circ}$ do C.C.

87 Também ao cônjuge é concedido um direito idêntico (art. 2103. ${ }^{\circ}$-A). Mas, nesse caso, não há vocação autónoma. Vide, sobre este ponto, infra, a nota 91.

${ }^{88}$ A falta de especificação não é, aliás, óbice à qualificação do sucessível como legatário. O chamamento a uma universalidade facto é, precisamente, um dos exemplos configurados pela doutrina como manifestações da figura do legado. RABINDRANATH CAPElo DE SOUSA, Lições de Direito das Sucessões cit., pp. 62 e 63.

89 Apesar de serem direitos distintos e não se poder considerar o direito de uso e habitação como modalidade do direito de usufruto. Sobre a distinção, Luís MENEZES LEITÃo, Direitos Reais cit., p. 349.

90 Assim FRANÇA PITÃO, no que respeita à redação introduzida pela Lei de 2010, refere-se-lhe como legatário legal. In Uniões de facto e Economia Comum, $3 .^{a}$ ed. cit., pp. 213 e 214 . 
dispor num sentido incompatível com a mesma, através de negócio jurídico mortis causa, unilateral ou bilateral (nos casos em que os pactos sucessórios são excecionalmente admitidos). Os efeitos previstos no art. 5. ${ }^{\circ}$, n. 1 da L.U.F. impõem-se, então, à vontade do unido de facto proprietário do imóvel em que se encontrava instalada a casa de morada da família e proprietário do respetivo recheio, sendo a sua vontade impotente para os afastar ${ }^{91}$, desde que, bem entendido, os bens sobre que os direitos incidirão venham a integrar o respetivo património hereditário.

Nesta ressalva, se deteta, uma primeira consequência de não nos encontrarmos perante uma manifestação da espécie de sucessão mortis causa legitimária, apesar da identidade da fonte (lei) e da imperatividade das normas em que se funda o chamamento dos herdeiros legitimários ${ }^{92}$ e o do unido de facto nos termos do $n .^{\circ} 1$ do

91 Nas palavras de GUILHERME DE OLIVEIRA, à luz da nova configuração introduzida em 2010, a lei revela que a proteção da casa de morada de família consubstancia "o núcleo irredutível da proteção conferida ao membro sobrevivo da união de facto e, portanto, garante a proteção mesmo contra a vontade do falecido". In Notas sobre a Lei n. ${ }^{\circ}$ 23/2010, de 30 de agosto (Alteração à Lei das Uniões de facto) cit., pp. 146 e 147 . Veja-se quanto ao art. $2103 .^{\circ}$-A relativo ao direito de uso e habitação reconhecido ao cônjuge que RABINDRANATH CAPELO DE SOUSA entende que constituirá "em parte" um exemplo de "legado legal". E é-o em parte, em virtude da singularidade da posição jurídica do cônjuge sobrevivo como herdeiro legitimário, "porque não há aí uma específica vocação sucessória susceptível de autónoma aceitação ou repúdio, nos termos gerais (artigos $2050 .^{\circ}$ e ss e $2249 .^{\circ}$ ), mas tão-só um direito de preferência do cônjuge sobrevivo, quando meeiro ou herdeiro aceitante, à composição da partilha e que ele pode exercer ou não". Por outro lado, "o valor do direito de habitação e de uso do recheio da casa vai integrar a quota do cônjuge sobrevivo, quer relativamente à parte sucessória, quer à sua meação nos bens comuns do casal, se a houver. O cônjuge sobrevivo continua herdeiro, mesmo que tenha de dar tornas no caso de tal valor exceder o que tem direito, havendo assim uma espécie de legado legal por conta da quota". Lições de Direito das Sucessões cit., p. 53, e nota 87. As singularidades acabadas de referir não se verificam no caso do unido de facto sobrevivo: nem ele é herdeiro legitimário, nem há nunca comunhão patrimonial idêntica à dos regimes de comunhão.

92 Aliás, a sucessão legitimária não se caracteriza (distinguindo-se da sucessão legítima) apenas pela sua natureza injuntiva. O legislador quis marcar a natureza diversa da sucessão legitimária e, por isso, autonomizou o capítulo que a ela respeita. ARMINDO RIBEIRO MENDES, Considerações sobre a natureza jurídica da legítima no Código Civil de 1966 cit., p. 16. José GONÇALVES DE PROENÇA debruça-se sobre as teses que negam autonomia à sucessão legitimária, reconduzindo-a à sucessão 
art. 5 da L.U.F.. Assim, o companheiro sobrevivo, apesar de poder ser encarado, nos termos referidos, como um sucessivel forçoso ${ }^{93}$, não é um sucessível legitimário ${ }^{94,95}$. Ele não integra o elenco de sucessíveis legitimários previsto no art. 2057. ${ }^{\circ}$ do C.C., inexistindo argumentos que imponham ou sequer permitam uma releitura deste preceito, por força do regime da L.U.F. para aí incluir o unido de facto sobrevivo ${ }^{96}$. Na verdade, este não beneficia dos mecanismos - alguns deles atuantes ainda em vida do autor da sucessão - da tutela predisposta pelo legislador em favor dos herdeiros legitimá-

legítima, rejeitando-as. A autonomização da sucessão legitimária radica na "análise histórico-jurídica da génese e do processo evolutivo" da legítima no direito português, ancorando-se, também, numa perspetivação de "ordem conceitual ou lógica". Natureza jurídica da "legítima», in Boletim da Faculdade de Direito, Suplemento IX, Coimbra, Universidade de Coimbra, 1951, pp. 446 a 458.

93 Embora o sucessível possa repudiá-la. Por isso, como sublinha GALVÃo TELLES, a sucessão legitimária é "forçada para o de cuius, não para os sucessíveis", já que "os interesses em causa são suficientemente importantes para sobrepor a sucessão legitimária à vontade do testador, mas não a ponto de a sobrepor à dos sucessíveis". In Direito das Sucessões. Noções Fundamentais cit., p. 103.

94 Sobre a origem e evolução da sucessão legitimária, considerando as suas raízes (distintas) no direito romano e no direito germânico, vide ARMINDO RIBEIRO MENDES, Considerações sobre a natureza jurídica da legítima no Código Civil de 1966 cit., pp. 6 a 14.

95 Repare-se que, no Anteprojeto da autoria de GALVão TELLES, se propunha a inclusão do cônjuge como sucessível legitimário, ao qual se atribuía o direito de usufruto de metade da herança, podendo concorrer com descendentes ou ascendentes do de cuius. A solução, apesar de aplaudida e aprovada na generalidade pela Comissão Ministerial (Ata n. ${ }^{\circ}$ 6, BMJ, n. ${ }^{\circ}$ 133, p. 154), foi depois excluída. Ao cônjuge reconhecia-se apenas o direito a ser alimentado pelos rendimentos dos bens deixados pelo falecido, nos termos do art. 2018. ${ }^{\circ}$. A proteção alimentar traduzida neste direito de apanágio do cônjuge mantém-se apesar de o cônjuge, com a reforma de 1977 , ter ascendido à categoria de herdeiro legitimário.

96 Para além de outras diferenças que exporemos de seguida, cumpre destacar que na sucessão legitimária manifesta-se uma indisponibilidade relativamente a uma quota hereditária (a legítima), cuja dimensão é variável, oscilando entre um mínimo de $1 / 3$ e um máximo de $2 / 3$, consoante os herdeiros legitimários que sejam chamados à herança, nos termos dos artigos $2158 .^{\circ}$ a $2162 .^{\circ}$. E calcula-se considerando o disposto no art. $2162 .^{\circ}$, o que significa que não consubstanciará apenas uma porção dos bens existentes no património do Autor da sucessão ao tempo da sua morte (relicta), devendo adicionar-se, aos relicta, os bens que já não se encontram em tal património, nesse momento, por o Autor da sucessão ter deles disposto gratuitamente (donata). 
rios para proteger a incolumidade da legítima ${ }^{97}$. Do que decorrerá, que a atribuição legal ao unido de facto sobrevivo será imputada na quota disponível, podendo ser reduzida para garantir a intangibilidade da legítima.

V. A expetativa do unido de facto, sendo uma expetativa juridicamente fundada, merece uma proteção frágil, muito diferente da que é outorgada aos herdeiros legitimários. Na verdade, o companheiro proprietário da casa de morada de família e dos bens móveis que integrem o seu recheio pode dispor deles livremente, por atos inter vivos, gratuitos ou onerosos, sem que o companheiro possa reagir contra os mesmos, e nesse caso, aqueles bens não integrarão a herança, inviabilizando-se, assim, a constituição dos direitos de uso e de habitação previstos no.$^{\circ} 1$ do art. $5 .^{\circ}$ da L.U.F..

Consequentemente, quando se diz que a vontade do de cuius não é eficaz para afastar a aplicação do disposto nessa norma98, pretende significar-se que o mesmo não a pode afastar por ato negocial unilateral ou bilateral mortis causa. Portanto, se o autor da sucessão tiver disposto do imóvel onde se situa a casa de morada de família ou do recheio da mesma, por testamento ou por doação mortis causa, a favor de outrem, a eficácia dessas disposições ficará dependente da concretização do efeito legalmente previsto naquele preceito, pelo que os bens se transmitem onerados com os referidos direitos reais menores de que o unido de facto sobrevivo é titular.

VI. O companheiro morador usuário do imóvel em que se situou a casa de morada de família e usuário do respetivo recheio será, portanto, um sucessível forçoso não legitimário. E nesta designa-

97 Sobre os mecanismos de proteção da legítima, vide RABINDRANATH CAPELO DE SOUSA, Lições de Direito das Sucessões cit., pp. 161 e ss.

98 A concretização com êxito da vontade de afastar essa aplicação poderá ocorrer, indiretamente, se o unido de facto proprietário da casa de morada de família e dos bens que compõem o respetivo recheio puser fim à relação antes de morrer ou se se desfizer da titularidade do direito real (de propriedade) sobre aqueles bens, alienando-os inter vivos. 
ção sucessória legal sui generis detetamos algumas das tendências que se têm manifestado no direito sucessório nas últimas décadas. Destacamos as seguintes: em primeiro lugar, a da gradual (e diferenciada) ampliação, também para efeitos sucessórios, da noção de família99; em segundo lugar, a da denominada horizontalização do direito das sucessões ${ }^{100}$, com favorecimento, em termos sucessórios, das relações de conjugalidade ou paraconjugalidade; em terceiro lugar, a da opção por chamamentos sucessórios que produzam a divisão entre sucessíveis do direito de propriedade e de direitos reais menores sobre o mesmo objeto ${ }^{101}$; finalmente, em quarto lugar, a da configuração dos efeitos sucessórios tomando em consideração a atitude pretérita do sucessível em relação ao de cuius, com a previsão de mecanismos diversos do da definição fixa do quid a que o sucessível vai ser chamado, em função da categoria abstrata em que o mesmo se insere ${ }^{102}$.

${ }^{99}$ A propósito das repercussões no direito sucessório da metamorfose operada nos contornos da noção da família, vide M. J. WAAL, A comparative Overview, in "Exploring the law of Succession. Studies National, Historical and Comparative", Edinburgh University Press, 2007, p. 7.

100 Sobre esse fenómeno, com a correspondente ilustração através do regime de direito das sucessões catalão, considere-se E. AMAYUELAS and M ANDERSON, Between tradition and modernisation, in The law of succession: testamentary freedom. European perspectives, Edited By M. Anderson and E. Amayuelas, European studies in private law (5), Groningen, European Law Publishing, 2011, pp. 58-62. E, considerando, o regime do direito holandês, J. MILO, Acquisition of property by succession in Dutch law, in The law of succession: testamentary freedom. European perspectives cit., pp. 217 e ss e 224 e ss.

101 W. PINTENS, Die Europäisierung des Erbrechts, in Zeitschrift für europäisches privatsrecht Zeup, 2001, 9, p. 631.

102 Aquilo que se denomina como "behaviour-based approach to succession rights". Veja-se, sobre este sentido evolutivo, A. ALOY, Freedom of testation, compulsory share and disinheritance based on lack of family relationship, in The Law of Succession: testamentary freedom. European perspectives cit., pp. 95 e ss. Assim, os dois pilares do direito das sucessões passam a ser: a contribuição para a formação da riqueza a partilhar e o cuidado prestado ao de cuius, i.e., "care and contribution". C. CASTELEIN, Imperative inheritance law in a late-modern society. Five perspectives: introduction and objectives, edited by C. Castelein, R. Foqué and A. Verbeke, Antwerp-Oxford-Portland, Intersentia, 2009, pp. 9 e ss. Tal orientação estará presente na possibilidade reconhecida no n. 4 do art. $5 .^{\circ}$ da L.U.F. de o Tribunal, 


\section{Observações conclusivas}

I. Procedemos à análise do regime jurídico previsto no art. $5 .^{\circ}$, n. $^{\circ}$ 1 a 9 da Lei 7/2001, de 11 de maio, na versão reformulada pela Lei n. ${ }^{\circ} 23 / 2010$, de 30 de agosto onde se prevê em benefício do unido de facto sobrevivo um conjunto complexo de direitos relativos à casa de morada da família e ao respetivo recheio, em caso de morte do companheiro proprietário dos mesmos. No percurso reflexivo que fizemos, detetámos vários pontos nublosos que enunciámos e para cujo esclarecimento procurámos contribuir.

II. O desaparecimento da possibilidade de derrogação por vontade do autor da sucessão do reconhecimento dos direitos previstos no n. $^{\circ} 1$ do art. $5 .^{\circ}$ da citada lei levou-nos, por fim, a equacionar a qualificação da posição jurídica do unido de facto morador usuário da casa de morada de família e usuário do respetivo recheio como sucessível do de cuius. Nesse percurso topámos, então, com um estranho caso de um legatário forçoso não legitimário, em cuja previsão vislumbramos a manifestação de várias tendências que caracterizam a evolução recente do direito sucessório.

por motivos de equidade, estender a duração dos direitos de uso e habitação para além dos limites fixados nos números 1 e 3 do mesmo artigo. 